\title{
Optimal index related to the shoreline dynamics during a storm: the case of Jesolo beach
}

\author{
Renata Archetti ${ }^{1}$, Agnese Paci ${ }^{1}$, Sandro Carniel ${ }^{2}$, and Davide Bonaldo ${ }^{2}$ \\ ${ }^{1}$ DICAM, University of Bologna, Bologna, Italy \\ ${ }^{2}$ CNR ISMAR, Venezia, Italy \\ Correspondence to: Renata Archetti (renata.archetti@unibo.it)
}

Received: 5 October 2015 - Published in Nat. Hazards Earth Syst. Sci. Discuss.: 24 November 2015

Revised: 22 March 2016 - Accepted: 1 April 2016 - Published: 12 May 2016

\begin{abstract}
The paper presents an application of shoreline monitoring aimed at understanding the response of a beach to single storms and at identifying its typical behaviour, in order to be able to predict shoreline changes and to properly plan the defence of the shore zone. On the study area, in Jesolo beach (northern Adriatic Sea, Italy), a video monitoring station and an acoustic wave and current profiler were installed in spring 2013, recording, respectively, images and hydrodynamic data. The site lacks previous detailed hydrodynamic and morphodynamic data.

Variations in the shoreline were quantified in combination with available near-shore wave conditions, making it possible to analyse the relationship between the shoreline displacement and the wave features. Results denote characteristic patterns of beach response to storm events, and highlight the importance of improving beach protection in this zone, notwithstanding the many interventions experimented in the last decades. A total of 31 independent storm events were selected during the period October 2013-October 2014, and for each of them synthetic indexes based on storm duration, energy and maximum wave height were developed and estimated. It was found that the net shoreline displacements during a storm are well correlated with the total wave energy associated to the considered storm by an empirical power law equation. A sub-selection of storms in the presence of an artificial dune protecting the beach (in the winter season) was examined in detail, allowing to conclude that the adoption of this coastal defence strategy in the study area can reduce shoreline retreat during a storm. This type of intervention can sometimes contribute to prolonging overall stability not only in the replenished zone but also in downdrift areas.
\end{abstract}

The implemented methodology, which confirms to be economically attractive if compared to more traditional monitoring systems, proves to be a valuable system to monitor beach erosive processes and provide detailed indications on how to better plan beach-maintenance activities. The presented methodology and the proposed results can therefore be used as a basis for improving the collaboration between coastal scientists and managers to solve beach erosion problems, in locations where data are scattered and sporadic.

\section{Introduction}

Being shorelines dynamic features that separate the land from the sea (Bellotti et al., 2003), they are impacted and continuously reshaped by waves, winds, currents, and human activities. Since $60 \%$ of the world's population lives within $100 \mathrm{~km}$ of the sea, monitoring shorelines is a primary social and economic task (García-Rubio et al., 2015), and it is very useful to understand the beach response to storm impacts with the purpose of a smart coastal planning. Furthermore, beach areas are among the most difficult environments to study because of the large quantity of data that are necessary to describe nearshore evolution and the incomplete understanding of the physical processes involved in this phenomenon. In fact, beach morphology is the result of complex, non-linear interplay among waves, currents and tides, which drive the sediment transport in a wide range of spatial and temporal scales (Alvarez-Ellacuria et al., 2011; Del Rio et al., 2013). A good management programme of seaside areas should address issues such as beach erosion and coastal 


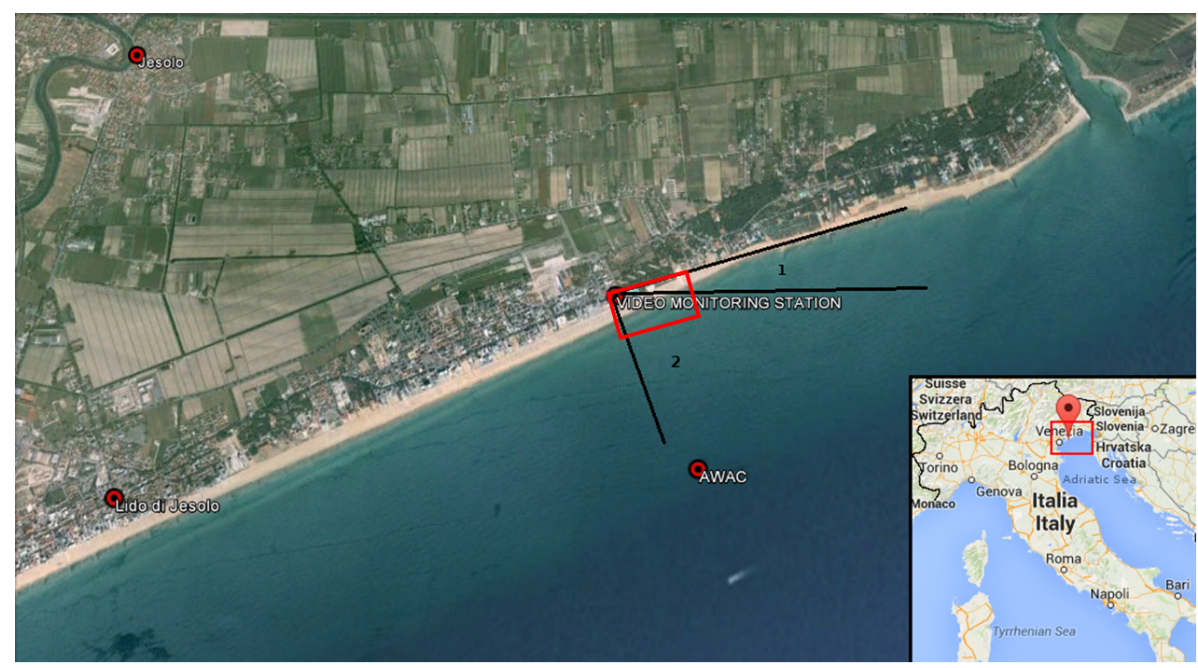

Figure 1. Satellite image of the site. The location of the AWAC and of the video-monitoring station are reported with red bullets, the angles of view of the two cameras are plotted in black, and the analysed section of beach is highlighted by the red square.

flooding and is of paramount importance for the economy of littoral cities.

This is indeed the case of the Jesolo seaside resort (Italy). Located in the NW sector of the Adriatic Sea (see Fig. 1) and capable of around 1000000 tourist arrivals and 5000000 bed-nights per year (Azienda di Promozione Turistica della Provincia di Venezia - Ufficio Studi \& Statistica - movimento turistico periodo gennaio-dicembre 2014, www.turismovenezia.it), Jesolo is the outpost of a low-lying alluvial plain in which eustasy $\left(1.53 \mathrm{~mm} \mathrm{yr}^{-1}\right.$, see Carbognin et al., 2004), subsidence (9.87 $\mathrm{mm} \mathrm{yr}^{-1}$, Tosi et al., 2006) and occasional storm surges exceeding $1.5 \mathrm{~m}$ (Zunica, 1990; Zampato et al., 2006) contribute to a severe flood risk in the area. Despite the relevant economic importance of the touristic activity within Jesolo area, very few data on the beach hydrodynamics and morphodynamics are available to coastal managers for the purpose of planning suitable beach management strategies, such as nourishments and sand movements. Furthermore, since the 1950s, this part of the Adriatic coast has undergone a number of attempts at a durable shore protection policy (Zunica, 1990), without coming to a fully satisfactory and conclusive solution.

For these reasons, within the framework of activities foreseen by the national flagship program "RITMARE - The Italian Research for the sea", this site has been identified as a strategic test area where integrated multi-disciplinary observational and numerical modelling efforts are implemented. The aim of this broad effort is to improve the knowledge on coastal dynamics and provide new strategies for monitoring and managing the coastal landscape and creating an early warning system that is essential for mitigating the loss of life and property from coastal flooding (Doong et al., 2012).

A suitable parameter for describing and monitoring the impact of storms on the shore (besides being a metric for the achievable income from touristic use) is typically the beach width and its evolution in time (Jimenez et al., 2007; Davidson et al., 2007; Harley et al., 2007; Archetti and Romagnoli, 2011; Archetti and Zanuttigh, 2010). Indeed, the impact of every single storm on the beach may induce short-term (for example, hours to days) morphodynamic responses that can significantly change the shoreline position (Jiménez et al., 2012) and threaten the sheltering function exerted by the littoral zone on the benefit of the mainland.

In recent years, several techniques for the monitoring of the shoreline position have been employed by the international community, some based on the use of kinematic DGPS, some on the use of images collected by satellites, and some others on the use of video images. The protocol of images acquisition was given by the ARGUS system (Holman and Stanley, 2007), and now the adoption of images collected by video-cameras or photo-cameras is widely used.

Each methodology has different pros and cons, but extensive risk mitigation and management practice generally requires moderate costs and the technical feasibility of largescale implementations. Given these conditions, the most economic and widespread (Wijnberg et al., 2005; Turner and Anderson, 2007; Kroon et al., 2007) is based on the registration of changes in the shoreline position using time-average images (timex), collected by a local video-camera station, where the swash effects are eliminated (Pardo-Pascual et al., 2014; Alvarez-Ellacuria et al., 2011). Compared to other indicators proposed as a proxy for the impact of storms, datum-based shoreline position has some specific advantages: it is possible to visually interpret the evolution in terms of shifts and rotations (if any), continuous images can be taken, even during storm peaks (which is only possible by using a remote sensor), it is a rather unsupervised and cheap approach, and it basically does not interfere with 
the environment (Alvarez-Ellacuria et al., 2011; Sénéchal et al., 2009). In contrast, occasional detection of sporadic shorelines through traditional methods such as GPS or satellite imagery can lead to unrealistic evolutionary beach trends (Kroon et al., 2007; Archetti, 2009). On the other hand, by relying on a video system it is possible to retrieve sufficient information to evaluate changes as effects of a storm, and in response to the impact of the maximum waves. The major limitation is related to the spatial coverage of the measurements (generally on the order of a few hundreds metres, Pardo-Pascual et al., 2014), but this problem can be overcome by the replicability of the method at an affordable cost. In fact, at the cost of about 10 GPS surveys on an equivalent coast stretch of $300 \mathrm{~m}$, it is possible to amortise the installation of a video station that is able to record more frequently a larger quantity of data, and during situations that a traditional GPS survey cannot measure.

In recent years the number of video station typologies for coastal monitoring has significantly increased, also due to the ability to obtain high-quality images at a low cost (Archetti and Zanuttigh, 2010; Vousdoukas et al., 2011), leading to the development of a methodology for automated mapping of the shoreline and intertidal beach position from video images (Uunk et al., 2010; Harley et al., 2007).

Besides morphological metrics, several parameters of interest for the analyses can be extracted from remotely sensed video images (Aarninkhof and Holman, 1999; Archetti and Lamberti, 2009), including surface currents (Archetti and Lamberti, 2007; Chickadel et al., 2003), wave breaking distributions (Lippmann et al., 1996) and wave run-up (Aagaard and Holm, 1989).

Through this system, scientists can provide direct support to coastal managers who want to protect the beach from erosion and need indications about the best timing and the best place to perform beach maintenance works. Moreover, timely indications could also be used as a warning for forecasting beach flooding, in order to increase the possibility of preventing damages (Archetti and Zanuttigh, 2010; Smit et al., 2007). In the framework of the integrated morphodynamic and hydrodynamic observation promoted by the RITMARE project, an acoustic system for the continuous measurement of vertical 3-D current profiles and wave spectral parameters approaching the coast and a video monitoring system were installed for a high-frequency survey. This is flanked by a morpho-bathymetric survey plan allowing a high-detail description of morphological features and their variations on a yearly base as well as the validation of the video monitoring system. This allows us to provide a detailed analysis of the impact on shoreline evolution of storms associated to different sea states and energy. Thus, the present study aims at exploring the potential of integrated videomonitoring and hydrodynamic measurement techniques as a tool for coastal risk management and for the development of more efficient defence interventions. This strategy is based on the identification of the relationship between wave condi- tions, as produced by sub-basin scale dynamics, and beach morphodynamic processes, supported by the definition of a synthetic parameter for the characterisation of the storm severity. Furthermore, this attempts to partially overcome the lack and sparsity of observational data that surprisingly affects an important tourist site such as Jesolo.

\section{Description of the area}

Jesolo is the main seaside resort on the northern Adriatic seashore, and among the most important along the whole Italian coast, attracting millions of international tourists every year. It is located in northeastern Italy, close to the northernmost end of the Venice Lagoon, and its littoral zone, stretching over $13 \mathrm{~km}$ in the SW-NE direction between the mouths of Sile and Piave rivers, is one of the longest sandy beaches in Italy. Due to its position, Jesolo beach undergoes the typical features of northern Adriatic wave climate, with the highest waves generated by Bora, a cold and typically dry northeasterly wind, and Scirocco, a southeasterly warm and humid wind blowing along the main axis of the basin (Russo et al., 2012; Benetazzo et al., 2012; Zavatarelli et al., 2003). The typical dynamics of Bora, blowing in jets from localised gaps along the eastern coastal mountain ridges, characterise these events with strong gustiness (up to $50 \mathrm{~m} \mathrm{~s}^{-1}$ ) and rapid growth and decay, whilst the fetch limitation characterise Bora-generated storms with relatively short and steep waves. On the other hand, storms generated by Scirocco generally impact the northern Adriatic coast with fully developed sea states, longer and more regular waves (Benetazzo et al., 2013), and are associated to relevant storm surges capable of partly flooding the historical centre of Venice.

During fall and winter season, Jesolo beach is mostly exposed to intense wind storms capable of mobilising a considerable amount of sediment and occasionally reshaping the beach. Due to the economic relevance of the large number of activities taking place on the sea (tourism, fishery, diving, etc.), Jesolo needs research activities that investigate marine and coastal dynamics and support an efficient coastal planning. The development of innovative monitoring approaches can lead to more efficient coastal management, e.g. providing strategic indications for periodic beach nourishments (Carniel et al., 2011), in the wake of the increasing awareness about coastal vulnerability issues.

Wave climate in the northern Adriatic Sea has been observed since the 1970 s by the Institute of Marine Science of the Italian National Research Council (CNRISMAR) at the Acqua Alta oceanographic tower (Cavaleri et al., 1999), located approximately $18 \mathrm{~km}$ off the Venetian coast $\left(45^{\circ} 18^{\prime} 83^{\prime \prime} \mathrm{N}, 12^{\circ} 30^{\prime} 53^{\prime \prime} \mathrm{E}\right)$. Besides wave data, a number of meteo-oceanic parameters are operationally observed, among which sea surface level, wind velocity and ocean currents vertical profiles (Benetazzo et al., 2013). Semipermanent wave conditions in the northern Adriatic Sea have 
a $0.5 \mathrm{~m}$ significant-wave height and about a $3.5 \mathrm{~s}$ wave period. Generally, the strongest storm conditions, generated by the Bora wind, consist of wave height up to $3.5 \mathrm{~m}$ and period of $7 \mathrm{~s}$ (Archetti, 2009). In addition to the Acqua Alta tower, a number of observatories collect tidal observations in the Adriatic Sea (Fenoglio-Marc et al., 2012), registering in Trieste and Venice the highest values for the Mediterranean Sea (respectively, 0.259 and $0.221 \mathrm{~m}$ as a M2 semi-diurnal amplitude and 0.197 and $0.185 \mathrm{~m}$ as a K1 diurnal amplitude, see Cushman-Roisin et al., 2002).

Focusing on the Jesolo coastal zone, our study site covers approximately $1.5 \mathrm{~km}^{2}$ on a beach stretch located approximately $3.5 \mathrm{~km}$ west of the Piave river mouth. The surveyed area ranges nearly $1 \mathrm{~km}$ in the long-shore direction and $1.5 \mathrm{~km}$ in the cross-shore direction, reaching an offshore depth of $10 \mathrm{~m}$ and enclosing the whole active beach (Bonaldo et al., 2014). For decades, this zone has been one of the most affected by coastal erosion on the entire water-facing side of the town. The progressive decrease of solid transport from the Piave River, the interruption of long-shore drift as an effect of jetty construction on the river mouth and the destruction of the dune belt for building purposes dramatically reduced sediment supply especially in this zone (Zunica, 1990), leading to insufficient sediment and to the absence, at present, of a decisive and successful shore-protection strategy. Indeed, hard structures are practically non-existent in this zone, except for a few groynes present downdrift and several hundreds metres updrift of the site. Instead, artificial dunes are generally built at the beginning of the winter season in the backshore and protected with a geotextile cover, while beach nourishments are usually carried out in spring. This solution is similar to the one described in Corbaut et al. (2009).

\section{Data and materials}

\subsection{Wave, sea level and wind data}

Vertical profiles of 3-D velocity components and directional spectral parameters of waves impacting the study site were recorded with a Doppler acoustic wave and current profiler (AWAC, Nortek, Rud, Norway) deployed $800 \mathrm{~m}$ offshore on a $7 \mathrm{~m}$ deep bottom, approximately at the limit of the active beach $\left(45^{\circ} 30^{\prime} 28^{\prime \prime} \mathrm{N} ; 12^{\circ} 41^{\prime} 33^{\prime \prime} \mathrm{E}\right.$, see Fig. 1). The mooring structure consisted of an aluminium framework stabilised by concrete blocks, hosting a removable polyethylene case containing the instrument and its battery canister, with permeable bottom for allowing sediment outflow during retrieval for maintenance and data downloading. Besides the traditional computation of velocity via analyses of the echo of a known emitted signal (1 MHz frequency for this device), the configuration of the four acoustic transducers installed in this system, together with an embedded pressure gauge, allow the reconstruction of the spectral parameters from an estimate of free water level oscillations (acoustic surface tracking) and orbital velocity statistics. An integrated orientation sensor records the rotation components of the instrument around three dimensions, permitting a retrospective control on the geotechnical stability of the system and on the fulfillment of the tolerance requirements for an appropriate operation of the wave measurements.

Current velocities along the water column were measured every $600 \mathrm{~s}$ within $50 \mathrm{~cm}$ cells, with a precision of 0.011 and $0.034 \mathrm{~m} \mathrm{~s}^{-1}$ on the vertical and horizontal directions, respectively. In turn, waves were sampled hourly by collecting 2400 samples at a $2 \mathrm{~Hz}$ sampling rate. In this configuration, the theoretical duration of the alkaline battery was about 100 days, but the real bottleneck for system maintenance was given by severe bio-fouling occurring in the shallow working environment that required inspections at least every month, especially in the summer season (Bonaldo et al., 2014).

Wave conditions were measured between March 2013 and October 2014. The instrument worked properly for most of the time. Ancillary wind data were collected on the Acqua Alta platform, approximately $26 \mathrm{~km} \mathrm{SSW}$ of the research area but still the closest sea observation point available for this purpose. An outlook on time series of wave height and period at Jesolo, together with wind records at Acqua Alta is provided in Fig. 2.

\subsection{Video monitoring station}

A video monitoring station, which constituted of two highresolution digital camera systems, was specifically set up for the project. The station was designed to record, without gaps, the response of the beach encompassed in the study area to the different meteomarine events, described in detail on the ocean side by the acoustic hydrodynamic measurements illustrated above. The video monitoring station was installed in July 2013 on the roof of a hotel facing the test area $\left(45^{\circ} 31^{\prime} 04^{\prime \prime} \mathrm{N}, 12^{\circ} 41^{\prime} 08^{\prime \prime} \mathrm{E}\right)$, which was chosen after a survey of the coastal tract, aiming to maximise the optical performance. It consists of two reflex digital cameras (10.1 megapixel, optical zoom), each hosted in a single waterproof case, and a management module (computer control unit of $1.6 \mathrm{MHz}, \mathrm{HD} 160 \mathrm{~GB}$; network interface controller Ethernet, modem UMTS/GSM/GPRS) allowing online monitoring and configuration. The control software package is composed of three modules: the first hosts the system management, controlling both image acquisition from all video station devices and image processing and uploading on the Web server using an FTP protocol; the second handles the remote connection and online servicing (setting changes, etc.), which allows real-time monitoring of the camera/video camera status and images and permits online system configuration; the third module hosts the Web server, enables downloading images and supports relocation to the Web server. Angle of view of the two cameras is shown in Fig. 1. 

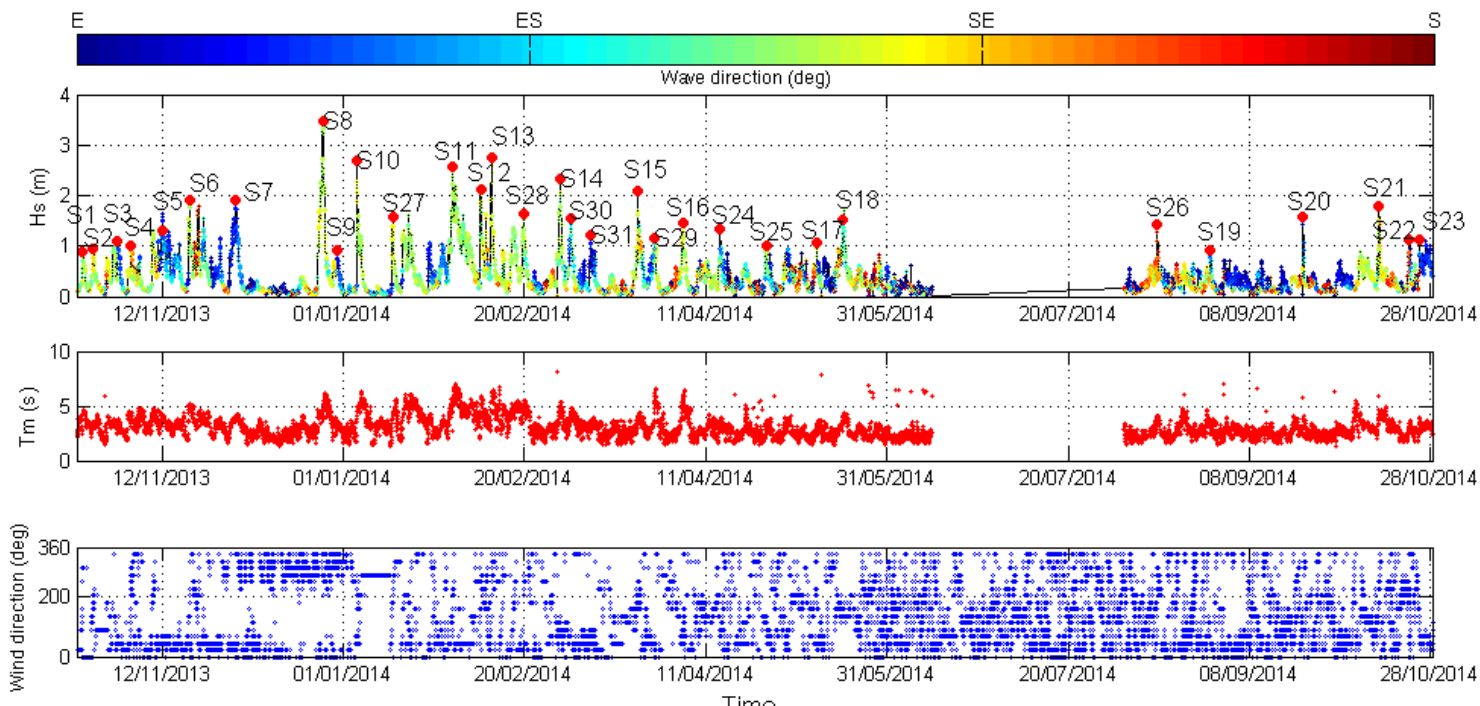

Figure 2. Time series of wave height $\left(H_{\mathrm{s}}\right)$, wave period $\left(T_{\mathrm{m}}\right)$ and wind direction in the analysed period.

Timex, or time exposure, images are produced by digitally averaging image intensity over a prescribed time interval of image acquisition (Fig. 3b) (Holman and Stanley, 2007) in order to remove random transient sea conditions and variability in run-up height. On the other hand, the detection interval needs to be sufficiently short to be referred to a contemporary water level. Images obtained by following this procedure are the basis for the identification of key topographic information, because the adopted technique leads to an increase in pixel colour intensity, enabling identification of peculiar beach features, such as sand bars morphology, shoreline positions, intertidal beach profiles and slopes, and morphological formations in the shoreface (Kroon et al., 2007). In this experiment, timex images are obtained by averaging 40 of the $15 \mathrm{~s}$ (exposure time) images over detection intervals of approximately $10 \mathrm{~min}$. The same methodology to obtain timex images was applied with still cameras at Igea Marina (Archetti and Zanuttigh, 2010), and it was verified that timex images obtained with the proposed methodology and the traditional methodology are comparable.

Instead, snapshot images (Fig. 3a) can offer information on the activities ongoing on the site: for example, it is possible to see when tractors and trucks are working on beach nourishments or preparing beach protections. In the presented study, images taken by Camera 1, NE oriented, were considered in order to analyse the last $300 \mathrm{~m}$ in the northern subregion of Jesolo beach.

\subsection{Bathymetry}

On 18 July 2013, and on 30 September 2014, two highresolution morpho-bathymetric surveys were carried out throughout the whole study area, with the multiple purpose of providing a reference bathymetry for an "initial state" of (a)

(b)

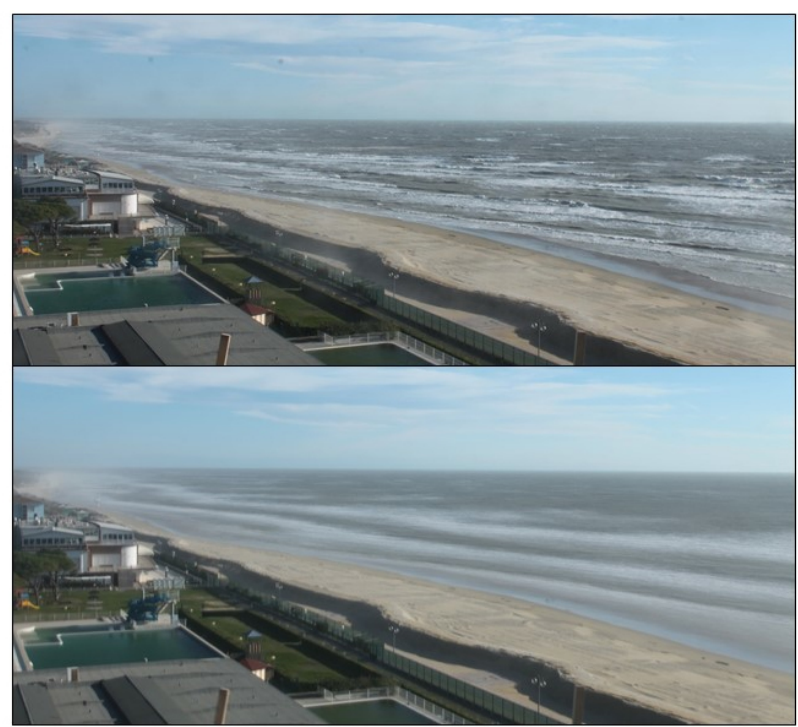

Figure 3. Examples of a snapshot image (a) and a timex image (b) in Jesolo beach.

all the work and for morphodynamic evaluations, showing inter-annual variations in the beach morphology and identifying couples of ground control points required for georeferenced image processing. During the surveys, the shoreline position was also detected and later used for validating its identification based on image processing. The subaerial and intertidal beach was surveyed with a Trimble (Sunnyvale, California) 5700 real-time kinematics (RTK) GPS system, collecting 27 transects with an average $50 \mathrm{~m}$ spacing. The sub-tidal beach, from the $1.5 \mathrm{~m}$ bathymetric contour line to the offshore limit of the domain, was surveyed by a Kongsberg (Norway) GeoSwath Plus 500 interferometric multi- 
beam, with $500 \mathrm{kHz}$ frequency, $240^{\circ}$ view angle and horizontal coverage up to 12 times the local water depth. Shallower sub-tidal zones were measured with a Teledyne Odom (Baton Rouge, Louisiana) Hydrotrac echosounder mounting a $200 \mathrm{kHz}$ transducer.

During the study period, surface sediment samples were collected with a van Veen grab sampler at different positions on the study site. Samples were subsequently dried and sieved obtaining granulometric curves within the 19$2000 \mu \mathrm{m}$ grain size range, allowing to classify the sediment as a silty sand.

\section{Methods and analysis}

The analysis, aiming at quantifying the shoreline response as a function of storms characteristics, consisted in the identification of relevant storms, selection of images taken before and after each storm, detection and comparison of shoreline positions on a stripe of the beach, quantification of mean displacement and finally correlation of the resulting displacement with the most suitable indicator of the storm severity. Since it allows us to easily correlate the characteristics of a storm and its effect on the beach, providing useful information to protect the area from flooding and damages, the identification of this indicator is indeed one of the main purposes of our study.

\subsection{Storm identification}

Individual storm events over the study period were identified from the recorded wave heights using the common methodology described by Boccotti (2000). The method is based on a preliminary identification of a wave height threshold, namely 1.5 times the annual average $H_{\mathrm{S}}$ (that is $0.58 \mathrm{~m}$ for the available wave data set described in Sect. 3). This order of magnitude for the threshold value was the same used in many papers concerning the North Adriatic area, for instance, in Archetti and Romagnoli (2011). In this way, it was possible to create a 1-year long list of storms occurred. As an example of application of this methodology to identify storms, the seventh recorded storm is illustrated below in detail, as representative of all the others. The relative recorded time series is presented in Fig. 5. This event began on 1 December 2013, at 01:00 LT, when the wave height overcame the defined threshold with a value of $0.91 \mathrm{~m}$, and it lasted until 3 December at 03:00 LT. After this time, the wave height decreased under the threshold value. The maximum wave height, $1.90 \mathrm{~m}$, occurred on 2 December at 09:00 LT. The total duration of this storm was $50 \mathrm{~h}$.

This procedure led to the identification of a total of 31 storm events in the period October 2013-October 2014, summarised in Table 1, as explained in the following section, not all these events, but only 29 , could be analysed because of malfunctions of video image station.

\subsection{Image pre-processing analysis}

The first step, after the identification of the relevant storms, consisted of selecting the most appropriate timex images, among those that passed the quality control phase, taken during calm days before and after the identified storms. In order to allow the evaluation of shoreline position net of sea level oscillations, images for every storm were selected in correspondence with the same values of sea surface elevation, retrieved a posteriori from the AWAC pressure gauge.

The video camera system did not save images always in the analysed period: for instance, from 14 to 25 February 2014 (28th storm) there are no images available. The same happened during the 30 th and the $22 \mathrm{nd}$ storms, and therefore these events are not considered in the analysis.

Image distortion was corrected with a MATLAB based open source Camera Calibration Toolbox (http://www. vision.caltech.edu/bouguetj/calib_doc/, Zhang, 1999; Tsai, 1987). The processed images were then rectified (i. e. projected from the image reference system into a user-specified horizontal plane, in this case the sea surface plan in world coordinates) by applying the collinearity equations (Weng et al., 1992; Lenz and Tsai, 1988; Slama, 1980) on seven pairs of ground control points (GCPs), whose real-world coordinates were surveyed during a dedicated field campaign.

An example of plan view (rectified image) of the surveyed beach, where the swimming pool next to the installation hotel and the beach umbrella lines are easily recognisable, is shown in Fig. 6. Coordinates are given in in UTM system units (m).

\subsection{Shoreline detection before and after the storm}

Many automatic procedures are available for the identification of shoreline position on images. Recently, Garcia-Rubio et al. (2015) presented a method based on the energy reflected in the NIR (near infrared) wavelengths, assuming that higher and lower intensities are related to the inherent physical properties of sea and land, respectively.

For camera images several methodologies have been developed (Aarnikhof and Roelvink, 1999). In the current analysis the shorelines were automatically detected on the rectified image, through an image processing tool specifically developed in the MATLAB environment. The methodology was the same applied in Archetti and Zanuttigh, (2010), based on a sub-pixel extraction of the line between water and non-water zones (Viet et al., 2014, Carniel et al., 2011; Vousdoukas et al., 2011; Archetti, 2009). Detected shorelines were then interpolated at $5 \mathrm{~m}$ spatial resolution. An example of rectified timex image and shoreline detected is presented in Fig. 6., whereas the ground-truth data are constituted by the waterline acquired at the same time of videoderived shoreline by a team operating a DGPS at RTK (realtime kinematic) mode during the topographic surveys (see Sect. 3.3). 
Table 1. List of the storm selected in the period October 2013-October 2014.

\begin{tabular}{|c|c|c|c|c|c|c|c|c|c|c|c|c|c|c|c|}
\hline & Start date & Peak date & End date & $\begin{array}{c}H_{\mathrm{S}} \\
(\mathrm{m})\end{array}$ & $\begin{array}{l}T_{\mathrm{p}} \\
(\mathrm{s})\end{array}$ & $\begin{array}{l}\text { Wave } \\
\text { dir. } \\
\text { (deg) }\end{array}$ & $\begin{array}{l}\text { Wind } \\
\text { dir. } \\
\text { (deg) }\end{array}$ & $\begin{array}{c}\text { Storm } \\
\text { duration } \\
\text { (h) }\end{array}$ & $\begin{array}{r}\text { M.S.L. } \\
\text { (m) }\end{array}$ & $\begin{array}{l}\Delta x \\
(\mathrm{~m})\end{array}$ & $\begin{array}{c}\operatorname{Max} \Delta x \\
\text { during the peak } \\
\text { (m) }\end{array}$ & $\begin{array}{r}\text { Wave } \\
\text { energy } \\
H_{\mathrm{s}}^{2} T \\
\left(\mathrm{~m}^{2} \mathrm{~s}\right)\end{array}$ & $\begin{array}{c}\text { Storm } \\
\text { power } \\
\text { index } \\
\left(\mathrm{m}^{2} \mathrm{~h}\right)\end{array}$ & $\begin{array}{l}\text { Storm } \\
\text { energy } \\
\left(\mathrm{m}^{2} \mathrm{~s}\right)\end{array}$ & $\begin{array}{l}\text { Distance of } \\
\text { the pre-storm } \\
\text { from the } \\
\text { baseline }(\mathrm{m})\end{array}$ \\
\hline $\mathrm{S} 1$ & $19 / 10 / 13$ & $21 / 10 / 13$ & $22 / 10 / 13$ & 0.88 & 4.10 & 140 & 22 & 2 & 0.30 & 0.62 & 4.10 & 3.18 & 1.55 & 5.87 & 55.89 \\
\hline $\mathrm{S} 2$ & $22 / 10 / 13$ & $24 / 10 / 13$ & $26 / 10 / 13$ & 0.95 & 3.50 & 141 & 130 & 4 & 0.04 & 1.39 & 3.50 & 3.16 & 3.61 & 10.56 & 51.96 \\
\hline S3 & $26 / 10 / 13$ & $30 / 10 / 13$ & $01 / 11 / 13$ & 1.10 & 3.47 & 99 & 45 & 38 & 0.14 & 1.44 & 3.47 & 4.20 & 45.98 & 86.99 & 56.68 \\
\hline $\mathrm{S} 4$ & $01 / 11 / 13$ & $03 / 11 / 13$ & $06 / 11 / 13$ & 1.00 & 4.38 & 145 & 23 & 9 & 0.53 & 4.71 & 4.38 & 4.38 & 9.00 & 30.25 & 53.34 \\
\hline S5 & $06 / 11 / 13$ & $12 / 11 / 13$ & $18 / 11 / 13$ & 1.30 & 4.42 & 139 & 45 & 117 & 0.37 & 4.40 & 4.42 & 7.47 & 197.73 & 399.42 & 50.68 \\
\hline S6 & $18 / 11 / 13$ & $19 / 11 / 13$ & $30 / 11 / 13$ & 1.91 & 4.54 & 138 & 45 & 214 & 0.28 & 4.87 & 4.54 & 16.56 & 780.69 & 521.16 & 57.58 \\
\hline S7 & $30 / 11 / 13$ & $02 / 12 / 13$ & $06 / 12 / 13$ & 1.90 & 3.96 & 104 & 45 & 50 & 0.24 & 3.17 & 3.96 & 14.30 & 180.50 & 320.68 & 52.68 \\
\hline S8 & $24 / 12 / 13$ & $26 / 12 / 13$ & $28 / 12 / 13$ & 3.48 & 4.78 & 139 & 45 & 51 & -0.32 & 6.13 & 4.78 & 57.89 & 617.63 & 991.34 & 70.8 \\
\hline S9 & $28 / 12 / 13$ & $30 / 12 / 13$ & $31 / 12 / 13$ & 0.92 & 3.69 & 107 & 22 & 3 & -0.25 & -1.55 & 3.69 & 3.12 & 2.54 & 8.58 & 56.51 \\
\hline S10 & $03 / 01 / 14$ & $04 / 01 / 14$ & $06 / 01 / 14$ & 2.70 & 3.87 & 135 & 160 & 34 & 0.21 & 3.90 & 3.87 & 28.21 & 247.86 & 305.79 & 53.21 \\
\hline S11 & $29 / 01 / 14$ & $31 / 01 / 14$ & $02 / 02 / 14$ & 2.58 & 5.29 & 139 & 160 & 84 & 0.14 & 9.60 & 5.29 & 35.21 & 559.14 & 1143.5 & 41.11 \\
\hline $\mathrm{S} 12$ & $07 / 02 / 14$ & $08 / 02 / 14$ & $10 / 02 / 14$ & 2.11 & 3.05 & 140 & 270 & 46 & 0.00 & 3.66 & 3.05 & 13.58 & 204.80 & 303.07 & 53.58 \\
\hline $\mathrm{S} 13$ & $10 / 02 / 14$ & $10 / 02 / 14$ & $12 / 02 / 14$ & 2.75 & 4.42 & 135 & 225 & 21 & -0.04 & 2.65 & 4.42 & 33.43 & 158.81 & 328.94 & 51.97 \\
\hline S14 & $28 / 02 / 14$ & $01 / 03 / 14$ & 03/03/14 & 2.34 & 5.32 & 140 & 113 & 23 & -0.14 & 1.15 & 5.32 & 29.13 & 125.94 & 261.21 & 59 \\
\hline S15 & $21 / 03 / 14$ & $23 / 03 / 14$ & $26 / 03 / 14$ & 2.08 & 3.24 & 138 & 157 & 43 & 0.10 & 6.26 & 3.24 & 14.02 & 186.04 & 189.55 & 57.73 \\
\hline S16 & $31 / 03 / 14$ & $04 / 04 / 14$ & $06 / 04 / 14$ & 1.47 & 5.50 & 144 & 45 & 22 & 0.08 & 4.29 & 5.50 & 11.88 & 47.54 & 139.26 & 56.59 \\
\hline S17 & $09 / 05 / 14$ & $11 / 05 / 14$ & $15 / 05 / 14$ & 1.07 & 3.47 & 142 & 67 & 6 & 0.01 & 1.02 & 3.47 & 3.97 & 6.87 & 17.6 & 56.4 \\
\hline S18 & $15 / 05 / 14$ & $18 / 05 / 14$ & $22 / 05 / 14$ & 1.39 & 4.10 & 130 & 157 & 47 & -0.18 & 1.28 & 4.10 & 7.92 & 90.81 & 194.94 & 63.17 \\
\hline S19 & $26 / 08 / 14$ & $28 / 08 / 14$ & $30 / 08 / 14$ & 0.91 & 3.76 & 115 & 67 & 7 & 0.19 & 2.00 & 3.76 & 3.11 & 5.80 & 17.82 & 51.51 \\
\hline $\mathrm{S} 20$ & $19 / 09 / 14$ & $22 / 09 / 14$ & $26 / 09 / 14$ & 1.59 & 3.85 & 100 & 135 & 5 & 0.33 & 3.45 & 3.85 & 9.73 & 12.64 & 25.58 & 58.2 \\
\hline $\mathrm{S} 21$ & $07 / 10 / 14$ & $13 / 10 / 14$ & $23 / 10 / 14$ & 1.78 & 4.69 & 152 & 247 & 126 & 0.34 & 1.70 & 4.69 & 14.86 & 399.22 & 183.01 & 50.65 \\
\hline $\mathrm{S} 23$ & $23 / 10 / 14$ & $24 / 10 / 14$ & $28 / 10 / 14$ & 1.14 & 3.51 & 104 & 90 & 7 & 0.41 & 2.20 & 3.51 & 4.56 & 9.10 & 26.03 & 50.78 \\
\hline $\mathrm{S} 24$ & $13 / 04 / 14$ & $15 / 04 / 14$ & $16 / 04 / 14$ & 1.34 & 3.54 & 92 & 90 & 8 & 0.10 & 3.07 & no images & 6.36 & 14.36 & 30.47 & 58.13 \\
\hline $\mathrm{S} 25$ & $26 / 04 / 14$ & $27 / 04 / 14$ & $28 / 04 / 14$ & 1.01 & 3.09 & 150 & 135 & 5 & 0.20 & 1.87 & -0.46 & 3.15 & 5.10 & 17.56 & 53.17 \\
\hline S26 & $12 / 08 / 14$ & $13 / 08 / 14$ & $14 / 08 / 14$ & 1.42 & 4.02 & 160 & 225 & 3 & 0.24 & 2.86 & 6.90 & 8.11 & 6.05 & 18.81 & 56.83 \\
\hline S27 & $13 / 01 / 14$ & $14 / 01 / 14$ & $16 / 01 / 14$ & 1.58 & 4.27 & 145 & 225 & 10 & 0.31 & 5.20 & 7.14 & 10.66 & 24.96 & 64.1 & 59.4 \\
\hline S29 & $26 / 03 / 14$ & $27 / 03 / 14$ & $30 / 03 / 14$ & 1.17 & 3.47 & 107 & 45 & 7 & 0.17 & 3.13 & 3.7 & 4.75 & 9.58 & 29.34 & 57.36 \\
\hline S31 & $09 / 03 / 14$ & $10 / 03 / 14$ & $11 / 03 / 14$ & 1.21 & 3.44 & 100 & 90 & 7 & -0.29 & 2.44 & 4.4 & 5.04 & 10.25 & 27.46 & 69.48 \\
\hline
\end{tabular}

In the present paper, analyses relevant to the period October 2013-October 2014 focus on storm-induced shortterm changes in the shoreline position. In detail, the procedure to quantify the storm-induced shoreline variation, described also in Aarninkhof and Roelvink (1999), Aarninkhof et al. (2003), and Archetti and Lamberti (2009), is generally based on three steps. First, timex images collected immediately before and after the storm, at time of comparable sea water level (measured by the AWAC pressure gauge) are selected. Second, the position of the shoreline is detected on rectified timex images. Last, the distances between the two shorelines is calculated. For this reason, and in order to avoid bias due to wave set up, it was decided to select and analyse only images taken during good meteorological conditions (calm sea). Dedicated routines allowed to associate sea-water elevation and shoreline position. Due to the strict criteria to be fulfilled (comparable sea level, calm sea state and good visibility) and the limited availability of timex images (as a compromise between time resolution and storage, only four timex images per day were available), the selection of the images was a demanding operation.

Along the beach, over short temporal scales, such as those typical of a storm, shoreline position changes are not always homogeneous, but it was possible to observe different behaviours and responses to the marine events. Indeed, some parts of the beach can advance and others can retreat, filtering out changes with the opposite pattern with respect to a central section and giving rise to apparent temporary rotation
(Fig. 9), even though this is not a pocket beach (Ojeda and Guillén, 2008) and the magnitude of rotation is not particularly relevant. Often, short-term beach rotation is manifested as variation of beach volume and width due to the lateral movement of sand alongshore (Masselink and Short, 1993; Klein et al., 2002), but otherwise it can appear without any variation of volume and width. It is also possible that crossshore movements due to particular wave conditions that occurred during the previous days result in a net progression of the whole beach (Fig. 10). Two mechanisms can cause waveenergy dissipation on a beach impacted by waves: (i) waveenergy position retrieval by submerged sand bar accretion, and, more efficiently, (ii) alongshore sediment redistribution (Alvarez et al., 2011).

In Figs. 8-10, the blue line represents the shoreline before the storm and the green line the shoreline after the storm. For almost all of the conditions considered, as for example in the case of storm S7, we notice a retreat of the beach, enhancing the described mechanism (Figs. 8, 9). On the contrary, Fig. 10 shows that storm S9 induced a slight beach enlargement in response to a quite small wave height, but it is also possible to see that even a low power storm can modify the shoreline position, as explained in Sect. 4.1. Figure 11, moreover, shows the comparison between shorelines before (blue line) and during the peak (red line) of the analysed storm S7.

More information on the storm conditions and beach behaviour is presented in the next section. 


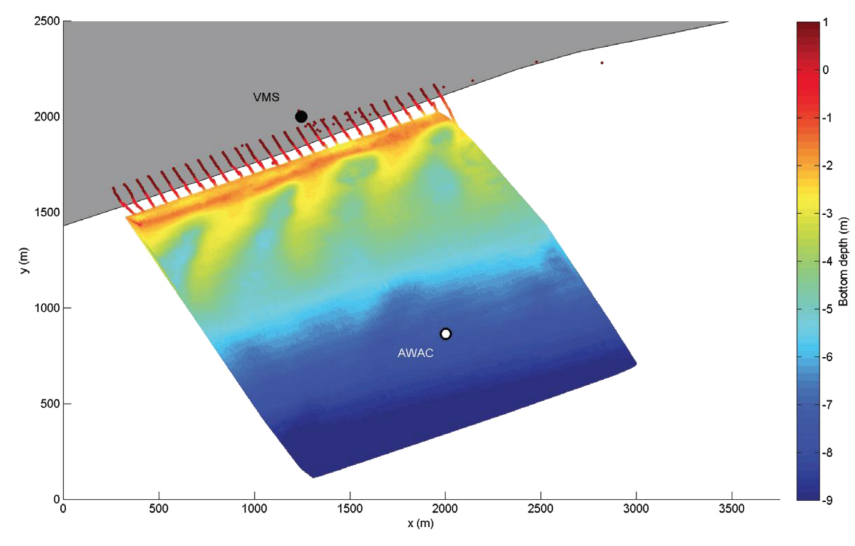

Figure 4. Bathymetry of the study area.
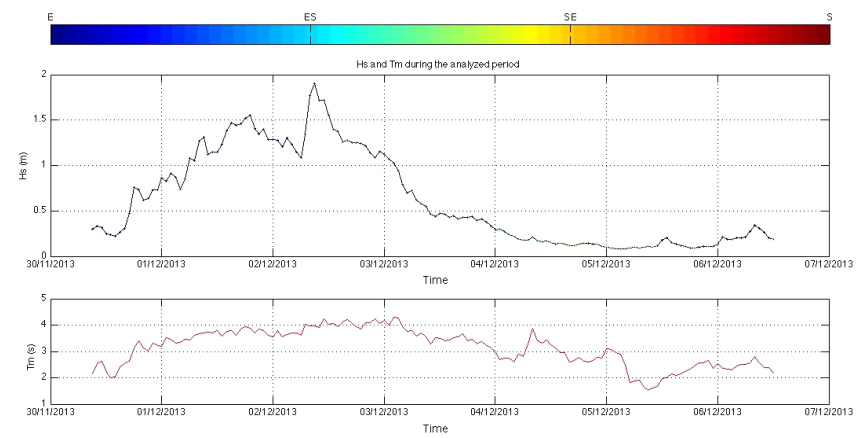

Figure 5. Time series of the 7 th storm.

\section{Results}

\subsection{Beach morphology and inter-annual variability}

The surveyed bathymetry is presented in Fig. 4, with bathymetry and later shoreline detection provided in UTM coordinate system and units in metres. Both RTK GPS surveys indicate that the beach slope in the intertidal zone was approx. $1: 15$.

A further estimation of the intertidal beach slope was performed also by analysing video images taken during calm days. The procedure was the same usually adopted to identify the intertidal beach position, described in Archetti and Romagnoli (2011), that is generally based on two steps. First, the position of the shoreline is detected on rectified timex images and horizontal distances between them are calculated $(\Delta x)$; and second, the associated vertical elevation $(\Delta h)$ is estimated from the sea level data (measured by the ADCP - Acoustic Doppler Current Profile). In this way, the average intertidal slope was the ratio $\Delta h / \Delta x$. We found a mean slope of $1: 16$, confirming the measurements based on GPS surveys performed in summer.

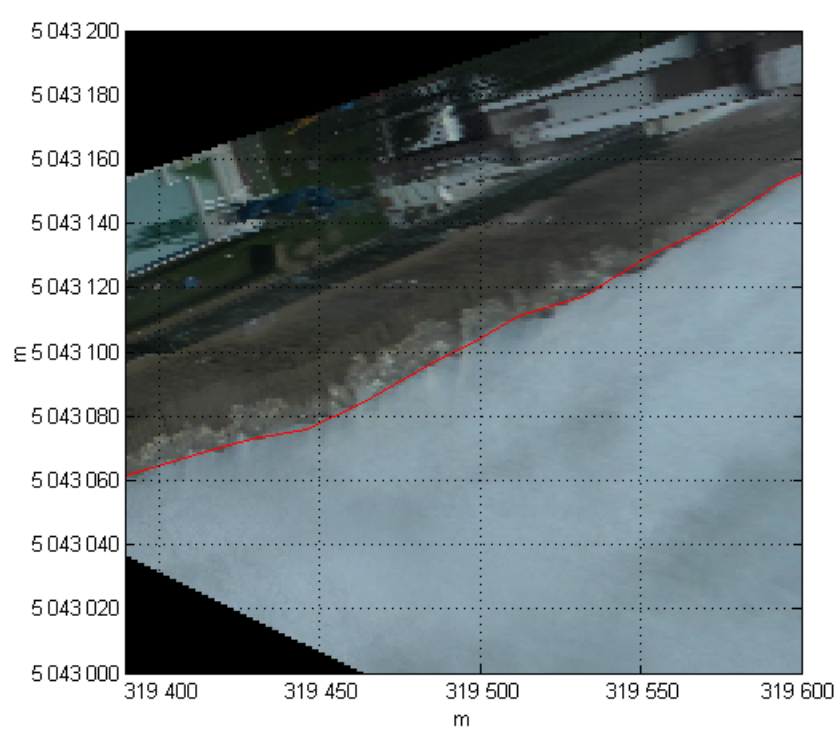

Figure 6. Shoreline detection on the rectified timex image during the 7 th storm.
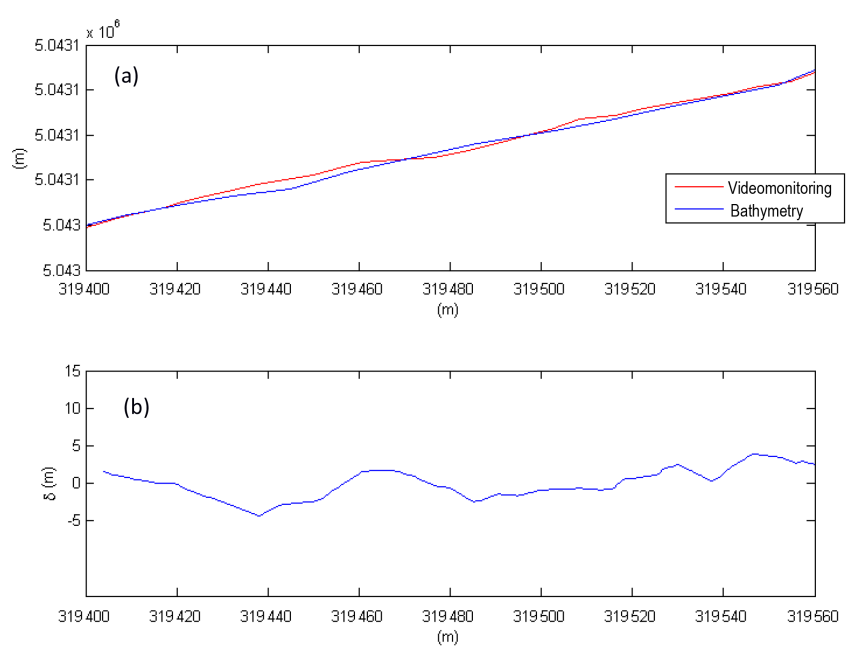

Figure 7. Comparison between video-image-derived and in situ RTK-GPS shorelines: (a) difference between shorelines detected from image (the red line) and from bathymetry survey (the blue line) date 30 September 2014; (b) the cross-shore deviation between the RTK-GPS shoreline and the image derived shoreline taken at the survey date. Negative deviation values represent a more landward video-derived shoreline.

\subsection{Shoreline detection accuracy}

The accuracy of the image-derived method was calculated comparing video-detected shorelines with the two GPS beach surveyed detected at the same time, hereinafter $\delta$ (surveys). This deviation was due to the ortho-rectification and the shoreline-detection processes.

In particular, the validation of the video-detected shoreline against the surveyed datum collected on 30 September 2014, 


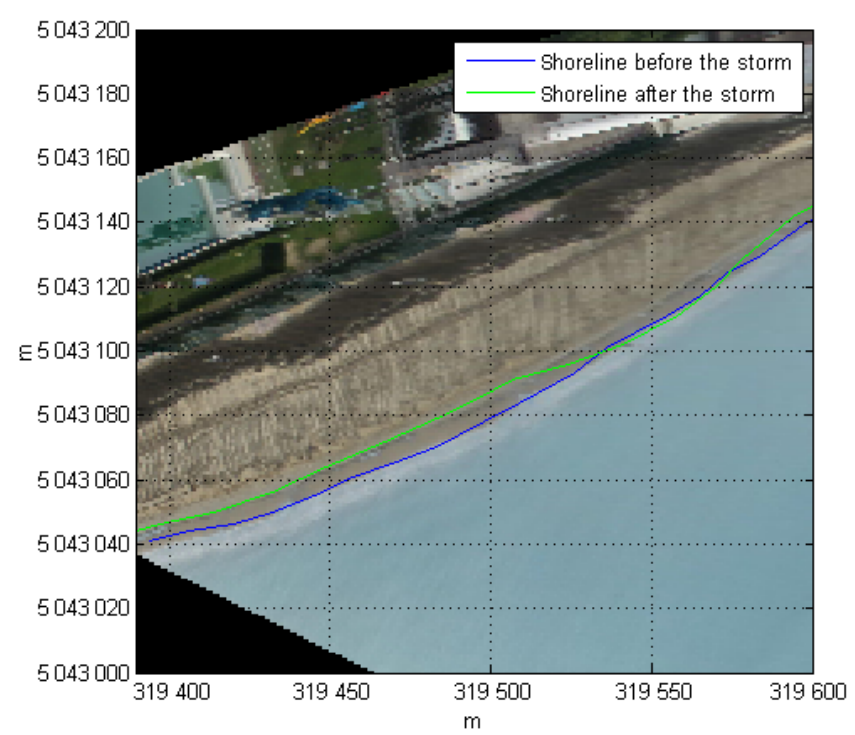

Figure 8. Detected shorelines, before and after the 7th storm.

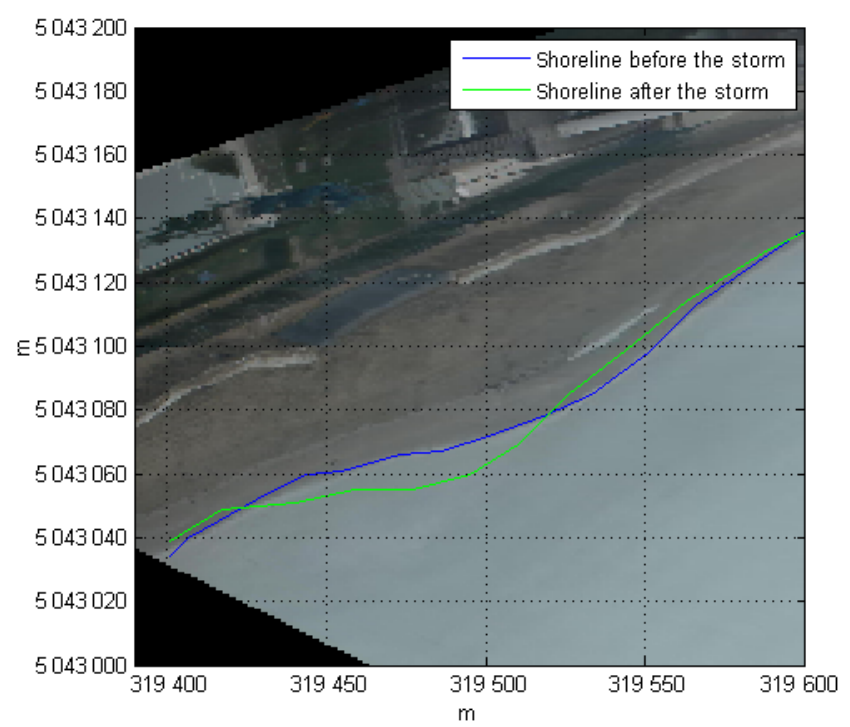

Figure 9. Detected shorelines, before and after the 14th storm, an example of the rotation of the beach.

showed a good agreement and the stability of the calibration carried out in July 2013 (Fig. 7). The mean distance, computed for shoreline located in the $300 \mathrm{~m}$ closer to the video station with reference to a set of 60 transects, was $1.59 \mathrm{~m}$ against data from the first survey, and $0.62 \mathrm{~m}$ for the second survey. The results indicated a mean value of $1.45 \mathrm{~m}$ as difference between the two lines, in the first $300 \mathrm{~m}$. The $\delta$ increased after the first $300 \mathrm{~m}$, as shown in Fig. 7. This error value was considered to be acceptable, since it was comparable to the excursion of the swash-zone during calm days and corresponded to $3-20 \mathrm{~cm}$ of vertical range for an average intertidal slope of $1: 15$. The evaluated error was on the same

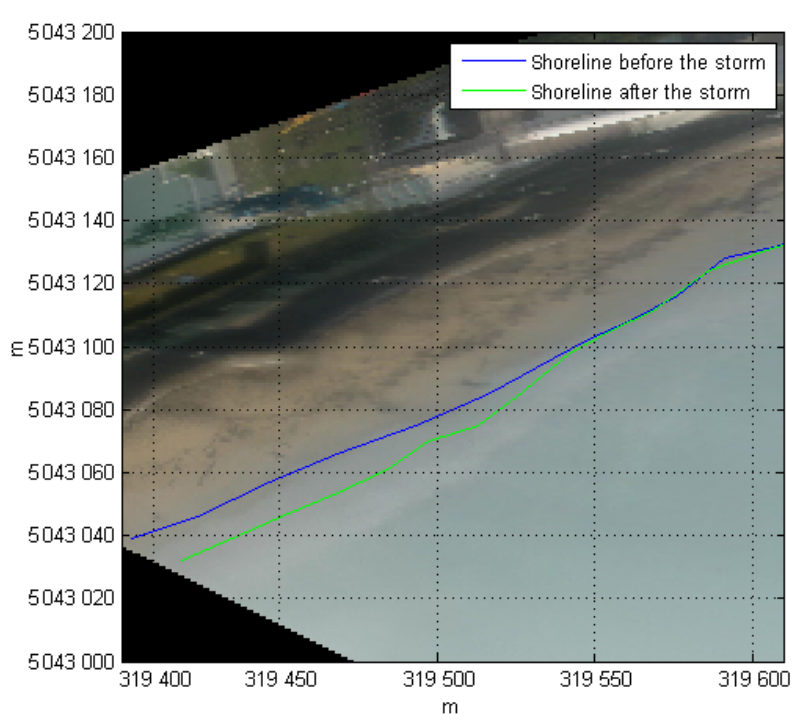

Figure 10. Detected shorelines, before and after the 9th storm, that induced a slightly enlarges of the beach.

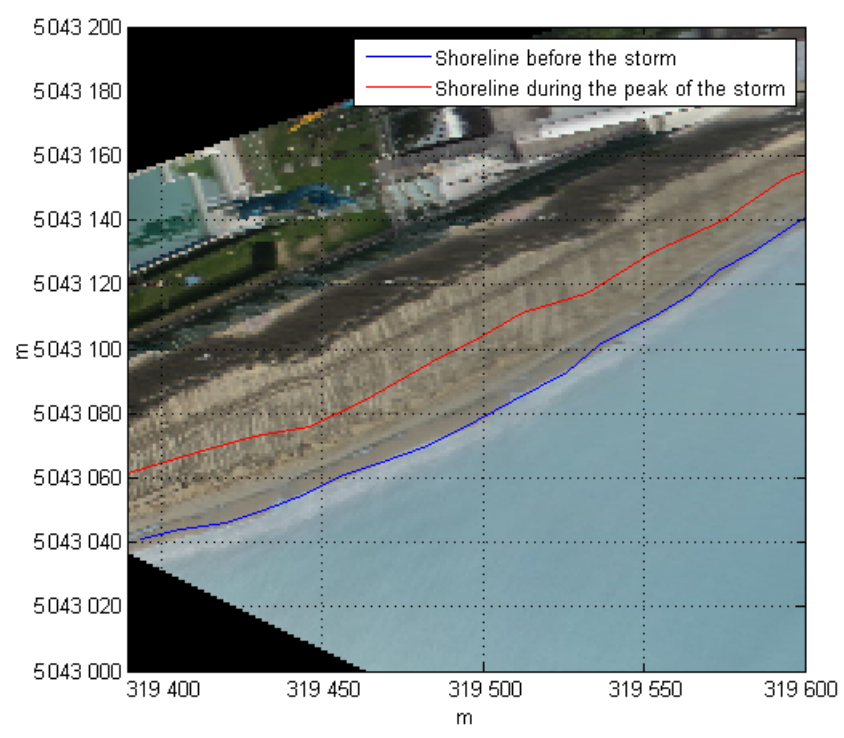

Figure 11. Detected shorelines, before and during the 7th storm.

order of magnitude, or less, than those obtained using video system for shoreline detection, as reported in many works (Archetti and Romagnoli, 2011; Ruiz de Alegria-Arzaburu and Masselink, 2010; Ruggiero and List, 2009; Holman and Stanley, 2007; Siegle et al., 2007; Harley et al., 2007; Elko et al., 2005; Holland et al., 1997).

\subsection{Beach evolution}

In order to describe how Jesolo beach reacts after significant storms, and to correlate this short-term beach evolution to the storm energy, the mean distance $\Delta x$ (difference in the crossshore direction between shoreline position after and before 


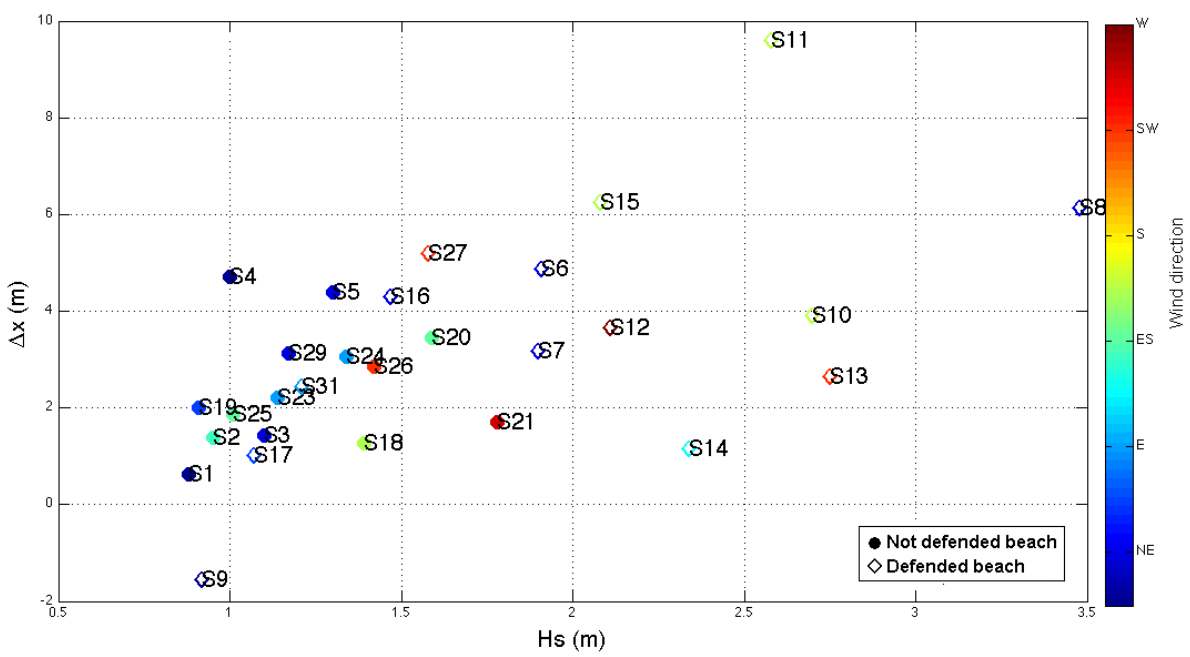

Figure 12. Relationship between wave height and shoreline displacement.

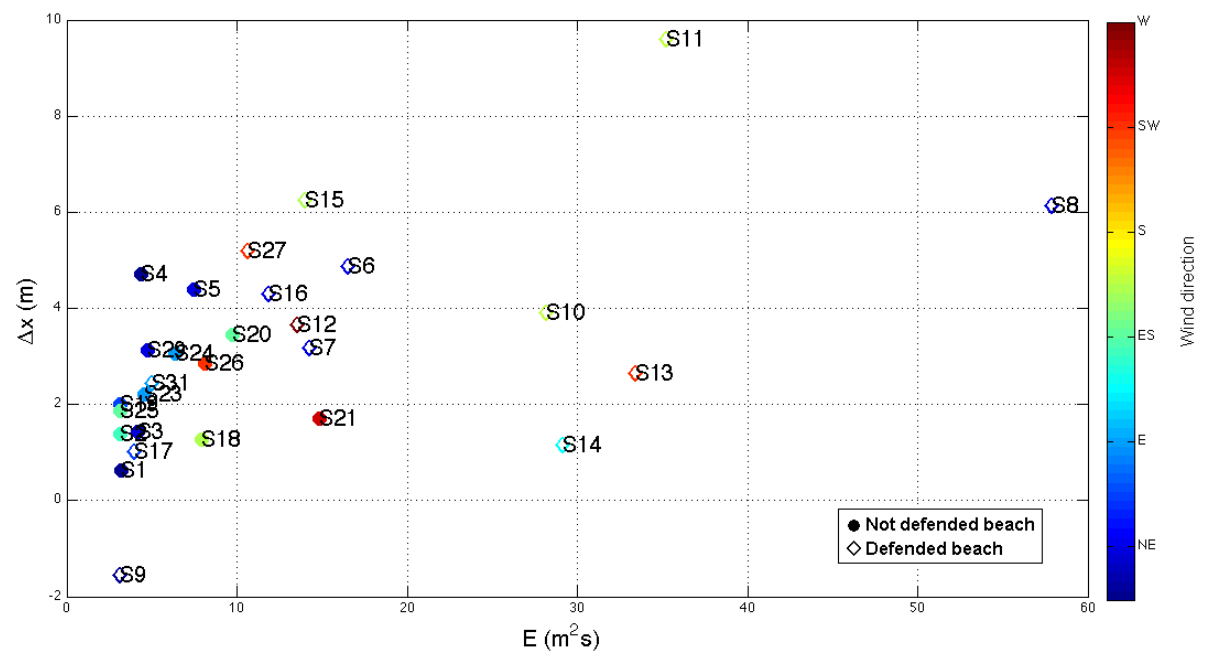

Figure 13. Relationship between wave energy and shoreline displacement.

the storm) was calculated for each selected event, as indicated in the Table 1 . The displacement of the shoreline during the storms was estimated for a set of $n=60$ transects on a $300 \mathrm{~m}$ long stretch of the beach.

The mean distance $\Delta x$ between the two shorelines was defined as

$\Delta x=\frac{\Sigma_{i} d_{i}}{n}$,

where $i$ were the transects $(i=1-60)$ and $d_{i}$ the distances in the cross-shore direction at every transect. Negative $\Delta x$ values indicated beach progradation, whilst positive values were associated with beach retreat.

In the analysed time frame (October 2013-October 2014), $\Delta x$ values varied commonly between 0.62 and $4.87 \mathrm{~m}$. Slightly higher positive values (from 5.20 to $9.60 \mathrm{~m}$ ) were observed during winter storms, the most intense stormy peri- ods. Only the 9 th storm gave a negative $\Delta x$ value $(-1.55 \mathrm{~m}$, see Fig. 10), possibly due to the supply of sand mobilised during the strong previous storm and redistributed alongshore by this event.

The global evolution of the beach showed how a large retreat of the shoreline was not generally associated with the highest waves and the longest storms, but mainly with the cumulative effect of successive storms (Pardo-Pascual et al., 2014). In fact, a number of factors may explain the correlation observed between shoreline displacements and the storm features for each event. As suggested by some authors (Ruiz de Alegria-Arzaburu and Masselink, 2010; Ojeda and Guillén, 2008; Ortega-Sànchez et al., 2008; Dail et al., 2000) the shoreline behaviour may depend on antecedent beach conditions, and the previous morphological state should be considered, together with the along-shore gradients in the factors controlling coastal sediment drift, in order to pro- 


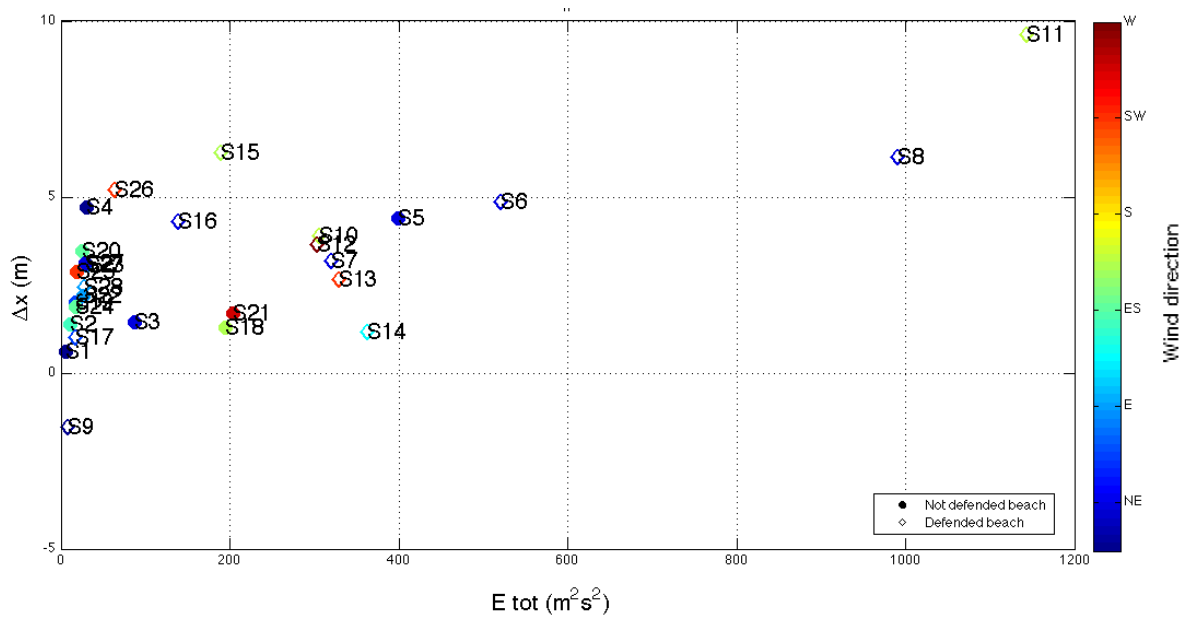

Figure 14. Relationship between total wave energy and shoreline displacement.

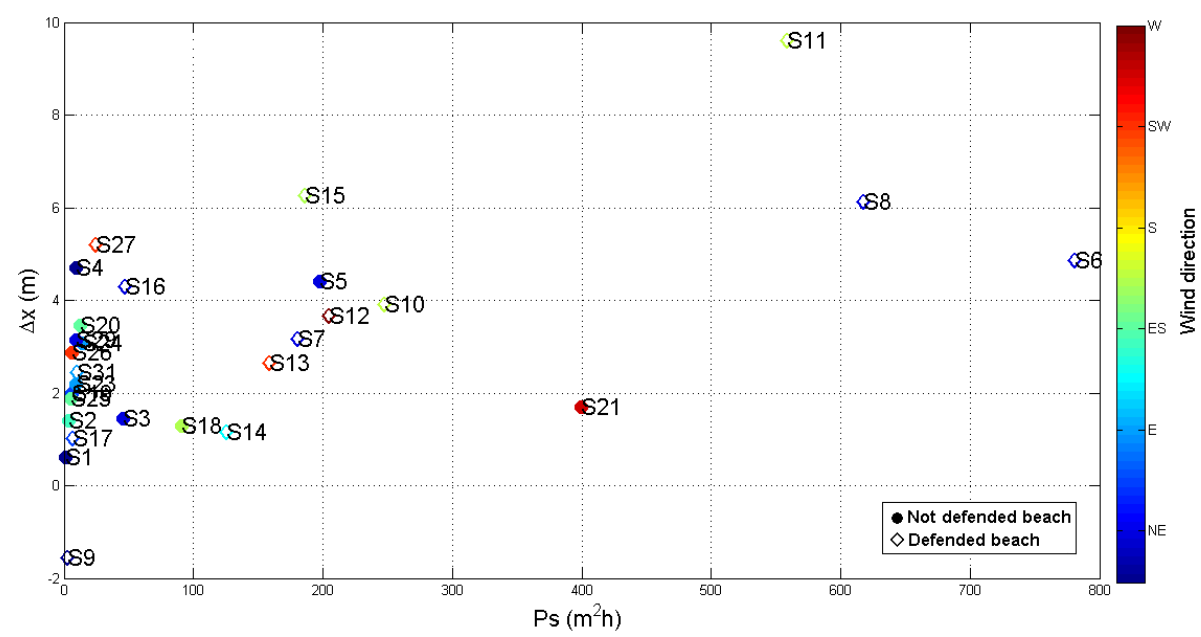

Figure 15. Relationship between $P_{\mathrm{S}}$ and shoreline displacement.

vide a detailed morphodynamic characterisation of the processes at the scale of a single event. In our case, a complete morphological description of the beach morphology was not available for each event; therefore upcoming evaluations will need to be considered in terms of statistical tendencies, rather than strictly prognostic of the details of morphodynamic processes undergone by the coastal tract in the presence of a given storm. Nevertheless, it was possible to calculate (and summarise in Table 1) the distance of each pre-storm shoreline from a baseline, identified as an interface between beach and hotel areas on an image collected on 30 August 2014. This quantity, though not adding any substantial information in terms of beach erosion, provides a record of shoreline displacements over the annual scale, not showing any strong seasonal behaviour and therefore suggesting that short-term dynamics may be dominating with respect to annual processes in this system.

\subsection{Index related to storm energy}

The correlation between beach response and sea conditions was finally investigated based on a preliminary evaluation of the outcomes of the measurement system with reference to specific storms. Four indexes were considered in the analysis to predict, with an empirical relationship, the shoreline displacement due to a forecasted storm under different conditions.

The four synthetic parameters are listed below:

- the maximum wave height during the storm: $H_{\max }[\mathrm{m}]$;

- the wave energy storm peak $E$ :

$$
E=H_{\max }^{2} \cdot T_{\mathrm{p}}\left[\mathrm{m}^{2} \mathrm{~s}\right]
$$


- the total energy during the storm, calculated as the integral of the product of $H^{2}$ and wave period $T_{\mathrm{p}} E_{\mathrm{tot}}$ :

$$
E_{\mathrm{tot}}=\int_{t_{1}}^{t_{2}} H^{2} T_{\mathrm{p}} \mathrm{d} t\left[\mathrm{~m}^{2} \mathrm{~s}^{2}\right],
$$

where $t_{1}$ and $t_{2}$ were the time of the begin and end of the storm;

- the storm power index (Dolan and Davies, 1994; Mendoza et al., 2011), calculated in order to obtain further insight the potential erosive events $P_{\mathrm{s}}$ :

$$
P_{\mathrm{s}}=H_{\max }^{2} \cdot d\left[\mathrm{~m}^{2} \mathrm{~h}\right],
$$

where $d$ is the duration of the "storm conditions" in hours and $H_{\max }$ is the maximum storm wave height (Senechal et al., 2015). $P_{\mathrm{S}}$ ranged between 1.5 and $780 \mathrm{~m}^{2} \mathrm{~h}$, with an average value of $132 \mathrm{~m}^{2} \mathrm{~h}$.

The analyses along all this period allowed for the detection of a large seasonal variability in the storm duration. 17 storm events were short-time, lasting less than $24 \mathrm{~h}$ and 11 events were longer storms from about 50 to $200 \mathrm{~h}$. In fact a wide range of storm cases was present in our database.

In December 2013, the area experienced a particularly strong storm event (storm 8) associated with a "storm power index" of $617 \mathrm{~m}^{2} \mathrm{~h}$ given by a $51 \mathrm{~h}$ duration of the storm and a $H_{\max }$ about $4 \mathrm{~m}$. Storm 6 presented even larger value for $P_{\mathrm{s}}$, up to $780 \mathrm{~m}^{2} \mathrm{~h}$, given by the remarkable duration of the storm $(214 \mathrm{~h})$, in spite of a $H_{\max }$ of $1.9 \mathrm{~m}$.

As summarised in Table 1, for all the storms we reported maximum $H_{\mathrm{s}}$ and period, duration, direction and wind direction, together with the corresponding $\Delta x$, the maximum displacement occurred during the storm peak and the indexes $E, E_{\mathrm{tot}}, P_{\mathrm{S}}$ and the distance of each pre-storm shoreline from a baseline.

Scatter plots representing the shoreline displacements as function of $H_{\mathrm{max}}, E, E_{\mathrm{tot}}$ and $P_{\mathrm{s}}$ are shown, respectively, in Figs. 12-15, in order to highlight the main relationships between these indexes and the shoreline displacement. Empty bullets in the plots indicate the storms occurred when the beach was protected by an artificial dune, generally in the winter season. In all the presented figures, the coloured bullets are related to the main wind direction generating the considered wave conditions in Jesolo beach. This information was necessary to understand the different features of the storms, showing that Bora storms (strong wind coming from North-East sectors) were generally the most energetic ones, and capable of inducing larger displacements of the shoreline based on all indexes. In Figs. 13 and 14, in which $\Delta x$ was related to the energy of the corresponding storm (respectively $E$ and $E_{\text {tot }}$ ), it was possible to identify a main trend, followed by most of the events. In particular, we can analyse in detail some of the results, in order to better understand the behaviour of Jesolo beach during the study period.
- S8 was the most energetic storm recorded, in term of wave height; during the storm the beach was protected, so the displacement was less than the expected one.

- S11 was characterised by a large wave height and a long storm duration, up to $84 \mathrm{~h}$. The sum of these two factors gave rise to a large value of storm energy. In fact, this was one of the few cases where sea water reached the protective artificial dune.

- S13 and S14 were associated to a very high $H_{\max }$ during the storm peak, 2.75 and $2.34 \mathrm{~m}$, but they lasted only 21 and $23 \mathrm{~h}$, respectively, and the protection of the beach avoided a great regression of the shoreline; this was probably the reason why the corresponding $\Delta x$ were small.

During S18, it was possible to see from snapshot images tractors and trucks working for nourishment on the beach. For this reason, this event cannot be considered in the analysis. In fact, despite a large maximum wave height $1.4 \mathrm{~m}$ and duration, which could be enough to produce a considerable $\Delta x$, the resulting storm effect on the beach retreat was modest.

Similar considerations can be drawn also looking the relationship between $H_{\max }$ and $\Delta x$. Worth noting, S4 and S5 had a high $\Delta x$ because they had not a protection, even though the wave height was not very big.

Moreover, it is possible to see that several highest energy storms, (namely S5, S6, S8, and a part of S11 that is characterised by the maximum duration), were generated by northeasterly winds (Bora).

Figure 15 provides a further evidence of the importance of the storm duration in determining the impact on the shore. In fact, as well as we already said about S8 and S11, also S6 had a high value of $P_{\mathrm{s}}$, due to its duration, $214 \mathrm{~h}$.

Based on these observations, we can confirm that the extensive adoption of artificial dunes (Fig. 16) in the study area was useful also to reduce shoreline retreat during the storm. This type of interventions can sometimes contribute to extend overall stability not only in the replenished zone but also in downdrift areas (Del Rio et al., 2013).

In the endeavour of identifying a suitable parameterisation for predicting the shoreline retreat $\Delta x$ in response to a storm event, we performed a fitting of this quantity against the four parameters listed above. Due to the strong variability observed in the beach response, besides using the full set of available measurements, the fitting was further tested for a number of data subsets. These were obtained by classifying the events by wind direction and beach dune conditions (Bora vs. Scirocco and protected vs. not protected, summarised in Table 2) or by overall storm energy (Low and High, with reference to a threshold of $300 \mathrm{~m}^{2} \mathrm{~s}^{2}$, summarised in Table 3). After some tests (not shown here) it was found that the power law of the form $\Delta x=a Y^{b}$, with $Y$ representing a generic storm characteristic, tendentially provided the best fit of the data, hence we referred to this case evaluating the fitting co- 


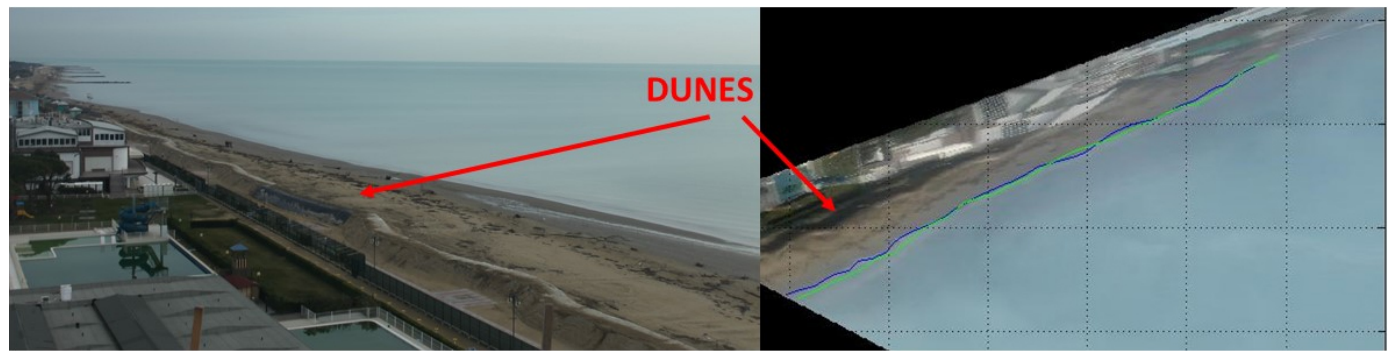

Figure 16. Artificial dunes, during the 9th storm, 30 December 2013, on a timex image and on a rectified image.

Table 2. Power law fit $\Delta x=a Y^{b}$ for storms classified based on wind direction and presence/absence of artificial protections.

\begin{tabular}{|c|c|c|c|c|c|c|c|c|c|c|c|c|c|}
\hline & & \multicolumn{4}{|c|}{ Protected } & \multicolumn{4}{|c|}{ Not protected } & \multicolumn{4}{|c|}{ Protected + non protected } \\
\hline & & ita & WaveEn & StormPow & StormEn & $H_{\mathrm{m}}$ & WaveEn & StormPow & StormEn & $H_{\mathrm{m}}$ & WaveEn & StormPow & StormEn \\
\hline \multirow{4}{*}{ 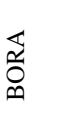 } & $a$ & 2.26 & 0.53 & 1.75 & 1.29 & 2.21 & 1.26 & 1.32 & 0.72 & 2.40 & 1.45 & 1.57 & 1.04 \\
\hline & $b$ & 1.66 & 1.04 & 0.16 & 0.20 & 0.85 & 0.40 & 0.22 & 0.30 & 0.79 & 0.37 & 0.19 & 0.25 \\
\hline & $R^{2}$ & 0.24 & 0.43 & 0.24 & 0.29 & 0.71 & 0.79 & 0.73 & 0.83 & 0.51 & 0.57 & 0.54 & 0.60 \\
\hline & RMSE & 1.32 & 1.15 & 1.33 & 1.28 & 1.10 & 0.93 & 1.07 & 0.85 & 1.18 & 1.10 & 1.13 & 1.06 \\
\hline \multirow{4}{*}{$\begin{array}{l}0 \\
\circlearrowright \\
0 \\
\approx \\
\tilde{n}\end{array}$} & $a$ & 1.42 & 0.81 & 2.00 & 2.00 & 2.98 & 4.21 & 0.05 & 0.14 & 1.56 & 0.85 & 0.10 & 0.22 \\
\hline & $b$ & 1.49 & 0.52 & 0.00 & 0.00 & 0.63 & 0.07 & 0.84 & 0.60 & 1.34 & 0.55 & 0.71 & 0.52 \\
\hline & $R^{2}$ & 0.45 & 0.33 & 0.00 & 0.00 & 0.01 & 0.00 & 0.76 & 0.56 & 0.35 & 0.32 & 0.63 & 0.54 \\
\hline & RMSE & 0.91 & 1.00 & 1.00 & 1.00 & 4.37 & 4.39 & 2.17 & 2.91 & 2.59 & 2.65 & 1.97 & 2.18 \\
\hline \multirow{4}{*}{$\begin{array}{l}+0 \\
+0 \\
\mathbb{\Delta} \\
0 \\
0 \\
\infty\end{array}$} & $a$ & 2.24 & 1.68 & 2.17 & 1.74 & 2.60 & 1.72 & 1.14 & 0.53 & 2.25 & 1.39 & 1.51 & 0.84 \\
\hline & $b$ & 0.46 & 0.22 & 0.04 & 0.09 & 0.66 & 0.31 & 0.26 & 0.37 & 0.80 & 0.36 & 0.19 & 0.29 \\
\hline & $R^{2}$ & 0.05 & 0.06 & 0.02 & 0.06 & 0.17 & 0.19 & 0.35 & 0.43 & 0.29 & 0.31 & 0.31 & 0.40 \\
\hline & RMSE & 1.23 & 1.22 & 1.14 & 1.22 & 2.22 & 2.19 & 1.96 & 1.84 & 1.72 & 1.70 & 1.70 & 1.58 \\
\hline
\end{tabular}

Table 3. Power law fit $\Delta x=a Y^{b}$ for storms classified based on high $\left(>300 \mathrm{~m}^{2} \mathrm{~s}^{2}\right)$ vs. low $\left(<300 \mathrm{~m}^{2} \mathrm{~s}^{2}\right)$ total storm energy.

\begin{tabular}{|c|c|c|c|c|c|c|c|c|c|c|c|c|c|}
\hline & & \multicolumn{4}{|c|}{ Low energy } & \multicolumn{4}{|c|}{ High energy } & \multicolumn{4}{|c|}{ High + low energy } \\
\hline & & $H_{\mathrm{m}}$ & WaveEn & StormPow & StormEn & $H_{\mathrm{m}}$ & WaveEn & StormPow & StormEn & $H_{\mathrm{m}}$ & WaveEn & StormPow & StormEn \\
\hline \multirow{4}{*}{$\begin{array}{l}+0 \\
+0 \\
\mathbb{d} \\
0 \\
0 \\
\infty\end{array}$} & $a$ & 2.20 & 1.71 & 2.10 & 1.70 & 3.38 & 1.87 & 0.36 & 0.06 & 2.25 & 1.39 & 1.51 & 0.84 \\
\hline & $b$ & 0.65 & 0.23 & 0.08 & 0.12 & 0.42 & 0.30 & 0.45 & 0.71 & 0.80 & 0.36 & 0.19 & 0.29 \\
\hline & $R^{2}$ & 0.12 & 0.09 & 0.05 & 0.06 & 0.07 & 0.17 & 0.46 & 0.85 & 0.29 & 0.31 & 0.31 & 0.40 \\
\hline & RMSE & 1.50 & 1.53 & 1.56 & 1.55 & 2.31 & 2.18 & 1.76 & 0.91 & 1.72 & 1.70 & 1.70 & 1.58 \\
\hline
\end{tabular}

efficients $a$ and $b$, the the root mean square error and the coefficient of determination $R^{2}$.

As a general trend, fitting results highlight that the presence of an artificial beach protection seems to significantly hamper the capability of a power law formulation of properly reproducing shoreline erosion (Table 2). On the other hand, the behaviour of an unprotected beach can satisfactorily be described by this model, especially in the case of Bora storms. In particular, the total energy impacting the beach and the storm power index appear more robust with respect to the criterion adopted for the classification, giving rise to overall better quality of fit compared to maximum wave height and wave energy at the storm peak. Retaining the information about the wave period, these parameters allow a more complete characterisation of the storm, better capturing the different behaviour associated to Bora and Scirocco, which in turn is strongly related to a different development of the sea state.

The classification criterion based on the generating wind direction allows us to identify the differences in the beach response to the storm event (worth noting, fitting coefficients for Bora and Scirocco are rather different, likely reflecting the differences in the sea state characteristics). Nevertheless, the best fit is given based on an energetic criterion, focusing on the storms characterised by total energy values exceeding $300 \mathrm{~m}^{2} \mathrm{~s}^{2}$ (Table 3). Indeed, in the face of best fits yielding

$\Delta x=0.84 E_{\text {tot }}^{0.29}$

for the whole data set, with $R^{2}=0.40$ and $\mathrm{RMSE}=1.58 \mathrm{~m}$, considering only the most energetic storms (generally the most harmful for coastal erosion concerns) the empirical relation becomes

$\Delta x=0.05 E_{\text {tot }}^{0.71}$. 


\section{Discussion and conclusions}

This paper proposes a method to study the short-term variability of a microtidal low-energy sandy beach morphology as a response to the impact of storms, by analysing the response of Jesolo beach in the period October 2013-October 2014. An integrated approach was used, merging images obtained from a video monitoring station with the analysis of the measured directional statistics of the sea climate impacting the shore.

The main goal of this work is to prove that the detection of the shoreline with a video station is a feasible, low-cost and efficient way to monitor and study beach processes, without interfering with the environment. Besides, it is one of the few (if not the only) instruments that allows us to view coastline dynamics during the storm. This technology becomes particularly efficient and versatile when complemented with wave data recorded by local instrumentations, such as an ADCP or buoys, and for supporting full process-based models as COAWST (Warner et al., 2010), MIKE2D, TELEMAC (i.e. Samaras et al., 2016) or reduced-complexity and data-driven models (van Maanen et al., 2015), in a longer temporal scale. Every video station can monitor about $300 \mathrm{~m}$ of beach very frequently, with a cost equivalent to approximately 10 GPS surveys. Furthermore, shoreline observations automatically retrieved from video monitoring images are able to add relevant information about the response of beach to storms impact in a better way than using satellite (e.g. Landsat images), because of the higher frequency and accuracy (Pardo-Pascual et al., 2014). Among different criteria available to characterise beach erosion and recovery processes, those based on shoreline position are particularly effective because through video monitoring it is possible to obtain frequent images covering a large segment of coast. Besides, this enables the identification of differences not only produced by a single event, but also by the cumulative effect of several storms.

Based on the 29 events selected for this study, we could describe and characterise the response of the beach shoreline to the different storms striking Jesolo beach. In general, the large amount of data collected provided a wealthy base for studying how beach recovery processes take place. We can also quantify the cumulative response of the beach in one year, both from shoreline response, comparing first and last survey, which showed an average beach width reduction of approximately $6 \mathrm{~m}$. Nevertheless, as explained previously, in the present application the cumulative result was strongly affected by beach management strategies, based on sporadic re-nourishment and sand redistribution on the beach. The short-term shoreline evolution description can be, however, a good index to outline the beach response at the event scale, which was not affected by human intervention (as nourishment and sand replacements). Thanks to all these data, it was possible to evaluate a set of empirical relations (summarised in Tables 2 and 3) linking shoreline retreat to storm characteristics in different conditions of wind, energy, and human intervention. The best fitting was obtained for $E_{\text {tot }}$, that can be therefore considered to be a good indicator of storm severity, accounting for wave height, period and storm duration.

Overall, results show that a prolonged storm with a small wave height is potentially capable of more severe erosion compared to one with a large wave height but short duration, and in particular, storms impacting the coast with the highest amount of energy are all generated by north-easterly winds (Bora).

When artificial protections were active, as during the winter season, measured displacement was limited, so we can deduce that the specific kind of coastal engineering work implemented was rather effective for this stretch of coast.

The method presented in this study could be used by coastal scientists to identify factors affecting morphological and hydrodynamic changes in the shore area and to give better information to managers about nourishments or protection works, as artificial dunes. For this reason, a wide-spread adoption of video monitoring techniques would allow the creation of a warning system for forecasting beach flooding and risk for beach users (Carniel et al., 2011).

The complex interactions among the processes acting on the littoral landscape enhance the relevance of observational approaches as a primary support for a broad set of applications in coastal management, from the prediction and management of the risk associated to single strong events to the identification of the emergent behaviours highlighting longterm evolution of the coastal tract.

Acknowledgements. This work was supported by Flagship Project RITMARE, The Italian Research for the Sea (SP3-WP4-AZ2), coordinated by the Italian National Research Council and funded by the Italian Ministry of Education, University and Research within the National Research Program 2011-2013.

The authors gratefully acknowledge the Jesolo Municipality (Comune di Jesolo), Jesolo Port Authority-Coast Guard (Capitaneria di Porto), Hotel Regent's, Jesolo Turismo SpA and Regione Veneto for providing support. The collaboration of Ril.Mar. and C. Badin is also acknowledged.

Edited by: S. Tinti

Reviewed by: two anonymous referees

\section{References}

Aagaard, T. and Holm, J.: Digitization of wave run-up using video records, J. Coastal Res., 5, 547-551, 1989.

Aarninkhof, S. G. J. and Holman, R. A.: Monitoring the nearshore with video, Backscatter, 10, 8-11, 1999.

Aarninkhof, S. G. J. and Roelvink, J. A.: Argus-based monitoring of intertidal beach morphodynamics, Coastal Sediments, 99, 24292444, 1999.

Aarninkhof, S. G. J., Turner, I. L., Dronkers, T. D. T., Caljouw, M., and Nipius, L.: A video-based technique for mapping intertidal beach bathymetry, Coast. Eng., 49, 275-289, 2003. 
Alvarez-Ellacuria, A., Orfila, A., Gómez-Pujol, L., Simarro, G., and Obregon, N.: Decoupling spatial and temporal patterns in shortterm beach shoreline response to wave climate, Geomorphology, 128, 199-208, 2011.

Archetti, R.: Quantifying the evolution of a beach protected by low crested structures using video monitoring, J. Coastal Res., 25, 884-899, 2009.

Archetti, R. and Lamberti, A.: Study of hydrodynamics induced by low crested structures through image processing, in: edited by: McKee Smith, J., Proceedings of the 30th International Conference, 3-8 September 2006, San Diego, California World Scientific Publishing Co., 5021-5033, 2007.

Archetti, R. and Lamberti, A.: Quantification by video monitoring of storm-driven shore changes of a beach protected by a low crested structure. Proc. the 31 st Int. Conf. on Coastal Eng, ASCE, 3, 1977-1989, 2009.

Archetti, R. and Romagnoli, C.: Analysis of the effects of different storm events on shoreline dynamics of an artificially embayed beach, Earth Surf. Proc. Land., 36, 1449-1463, 2011.

Archetti, R. and Zanuttigh, B.: Integrated monitoring of the hydromorphodynamics of a beach protected by low crested detached breakwaters, Coast. Eng., 57, 879-891, 2010.

Bellotti, G., Archetti, R., and Bocchini, M.: Experimental validation and characterization of mean swash zone boundary conditions, $\mathrm{J}$. Geophys. Res., 108, 3250, doi:10.1029/2002JC001510, 2003.

Benetazzo, A., Fedele, F., Carniel, S., Ricchi, A., Bucchignani, E., and Sclavo, M.: Wave climate of the Adriatic Sea: a future scenario simulation, Nat. Hazards Earth Syst. Sci., 12, 2065-2076, doi:10.5194/nhess-12-2065-2012, 2012.

Benetazzo, A., Carniel, S., Sclavo, M., and Bergamasco, A.: Wave-current interaction: Effect on the wave field in a semi-enclosed basin, Ocean Model., 70, 152-165, doi:10.1016/j.ocemod.2012.12.009, 2013.

Boccotti, P.: Wave Mechanics for Ocean Engineering, Elsevier Science, 2000.

Bonaldo, D., Archetti, R., and Carniel, S.: Monitoring Northern Adriatic Seashore At Jesolo Resort, Instruments in Northern Italy Seaside for Insight Into Coastal Dynamics, Sea Technol., 55, 5558, 2014.

Carbognin, L., Teatini, P., and Tosi, L.: Eustacy and land subsidence in the Venice Lagoon at the beginning of the new millennium, J. Marine Syst., 51, 45-353, doi:10.1016/j.jmarsys.2004.05.021, 2004

Carniel, S., Sclavo, M., and Archetti, R.: Towards validating a last generation, integrated wave-current-sediment numerical model in coastal regions using video measurements, Oceanol. Hydrobiol. St., 40, 11-20, doi:10.2478/s13545-011-0036-1, 2011.

Cavaleri, L.: The oceanographic tower Acqua Alta: more than a quarter of a century of activity, Societa Italiana Di Fisica, Il Nuovo Cimento C, 22, 1-111, 1999.

Chickadel, C. C., Holman, R. A., and Freilich, M. H.: An optical technique for the measurement of alongshore currents, J. Geophys. Res., 108, 3364, doi:10.1029/2003JC001774, 2003.

Corbaut, C., Simeoni, U., Archetti, R., Perettix, A., and Farina, M.: Winter sandy protections of the Northern Adriatic coast against flooding: Preliminary results, J. Coastal Res., 56, 1194-1198, 2009.

Cushman-Roisin, B. and Naimie, C. E.: A 3D finite-element model of the Adriatic tides, J. Marine Syst., 37, 279-297, 2002.
Dail, H. J., Merrifield, M. A., and Bevis, M.: Steep beach morphology changes due to energetic wave forcing, Mar. Geol., 162, 443458, 2000.

Davidson, D., Van Koningsveld, M., de Kruif, A., Rawson, J., Holman, R., Lamberti, A., Medina, R., Kroon, A., and Aarninkhof, S.: The CoastView project: Developing video-derived Coastal State Indicators in support of coastal zone management, Coast. Eng., 54, 463-475, 2007.

Del Río, L., Gracia, F. J., and Benavente, J.: Shoreline change patterns in sandy coasts. A case study in SW Spain, Geomorphology, 196, 252-266, 2013.

Dolan, R. and Davies, R. E.: Coastal storm hazards, J. Coastal Res., Special Issue No. 12, 103-114, 1994.

Doong, D.-J., Chuang, L. Z.-H., Wu, L.-C., Fan, Y.-M., Kao, C. C., and Wang, J.-H.: Development of an operational coastal flooding early warning system, Nat. Hazards Earth Syst. Sci., 12, 379390, doi:10.5194/nhess-12-379-2012, 2012.

Elko, N. A., Holman, R. A., and Gelfenbaum, G.: Quantifying the Rapid Evolution of a Nourishment Project with Video Imagery, J. Coastal Res., 21, 633-645, 2005.

Fenoglio-Marc, L., Braitenberg, C., and Tunini, L.: Sea level variability and trends in the Adriatic Sea in 1993-2008 from tide gauges and satellite altimetry, Phys. Chem. Earth, 40-41, 47-58, doi:10.1016/j.pce.2011.05.014, 2012.

García-Rubio, G., Huntley, D., and Russell, P.: Evaluating shoreline identification using optical satellite images, Mar. Geol., 359, 96105, 2015.

Harley, M. D., Turner, I. L., Short, A. D., and Ranasinghe, R.: Assessing the accuracy and applicability of a multi-decadal beach survey dataset, Proc. XXX ICCE, San Diego, USA, 4000-4008, 2007.

Holland, K. T., Holman, R. A., Lippmann, T. C., Stanley, J., and Plant, N.: Practical use of video imagery in nearshore oceanographic field studies, IEEE J. Oceanic Eng., 22, 81-92, 1997.

Holman, R. A. and Stanley, J.: The history and technical capabilities of Argus, Coast. Eng., 54, 477-491, doi:10.1016/j.coastaleng.2007.01.003, 2007.

Jimenez, A., Osorio, A., Marino-Tapia, I., Davidson, M., Medina, R., Kroon, A., Archetti, R., Ciavola, P., and Aarninkhof, S.: Beach recreation planning using video-derived coastal state indicators, Coast. Eng., 54, 507-521, 2007.

Jiménez, J. A., Sancho-García, A., Bosom, E., Valdemoro, H. I., and Guillén, J.: Storm induced damages along the Catalan coast (NW Mediterranean) during the period 1958-2008, Geomorphology, 143-144, 24-33, 2012.

Klein, A. H. F., Benedet Filho, L., and Schumacher, D. H.: Shortterm beach rotation processes in distinct headland bay beach systems, J. Coastal Res., 18, 442-458, 2002.

Kroon, A., Davidson, M. A., Aarninkhof, S. G. J., Archetti, R., Armaroli, C., Gonzalez, M., Medri, S., Osorio, A., Aagaard, T., Holman, R .A., and Spanhoff, R.: Application of remote sensing video systems for coastline management problems, Coast. Eng., 54, 493-505, 2007.

Lenz, R. K. and Tsai, R. Y.: Techniques for calibration of the scale factor and image center for high accurcy 3-D machine vision and metrology, IEEE T. Pattern Anal., 10, 713-720, doi:10.1109/34.6781, 1988. 
Lippmann, T. C., Brookins, A. H., and Thornton, E. B.: Wave energy transformation on natural profiles, Coast. Eng., 27, 1-20, 1996.

Masselink, G. and Short, D.: The Effect of Tide Range on Beach Morphodynamics and Morphology: A Conceptual Beach Model, J. Coastal Res., 9, 785-800, 1993.

Mendoza, E. T., Jimenez, J. A., and Mateo, J.: A coastal storms intensity scale for the Catalan sea (NW Mediterranean), Nat. Hazards Earth Syst. Sci., 11, 2453-2462, doi:10.5194/nhess-112453-2011, 2011.

Ojeda, E. and Guillén, J.: Shoreline dynamics and beach rotation of artificial embayed beaches, Mar. Geol., 253, 51-62, 2008.

Ortega-Sánchez, M., Fachin, S., Sancho, F., and Losada, M.: Relation between beachface morphology and wave climate at Trafalgar beach (Cádiz, Spain), Geomorphology, 99, 171-185, 2008.

Pardo-Pascual, J. E., Almonacid-Caballer, J., Ruiz, L. A., PalomarVázquez, J., and Rodrigo-Alemany R.: Evaluation of storm impact on sandy beaches of the Gulf of Valencia using Landsat imagery series, Geomorphology, 214, 388-401, 2014.

Ruggiero, P. and List, J. H.: Improving Accuracy and Statistical Reliability of Shoreline Position and Change Rate Estimates, J. Coastal Res., 25, 1069-1081, 2009.

Russo, A., Carniel, S., Sclavo, M., and Krzelj, M.: Climatology of the Central-Northern Adriatic Sea, in: Modern Climatology, edited by: Wang, S.-Y., InTech, Utah, USA, 37 pp., 2012.

Ruiz de Alegria-Arzaburu, A. and Masselink, G.: Storm response and beach rotation on a gravel beach, Slapton Sands, U.K., Mar. Geol., 278, 77-99, 2010.

Samaras, A. G., Gaeta, M. G., Moreno Miquel, A., and Archetti, R.: High resolution wave and hydrodynamics modelling in coastal areas: operational applications for coastal planning, decision support and assessment, Nat. Hazards Earth Syst. Sci. Discuss., doi:10.5194/nhess-2016-63, in review, 2016.

Sénéchal, N., Gouriou, B., Castelle, B., Parisot, J.-P., Capo, S., Bujan, S., and Howa, H.: Morphodynamic response of a meso- to macro-tidal intermediate beach based on a long term data set, Geomorphology, 107, 263-274, 2009.

Senechal, N., Coco, G., Castelle, B., and Marieu, V.: Storm impact on the seasonal shoreline dynamics of a meso- to macrotidal open sandy beach (Biscarrosse, France), Geomorphology, 228, 448$461,2015$.

Siegle, E., Huntley, D. A., and Davidson, M. A.: Coupling video imaging and numerical modeling for the study of inlet morphodinamics, Mar. Geol., 236, 143-167, 2007.

Slama, C. C.: Manual of Photogrammetry, 4th Edn., American Society of Photogrammetry, 1980.

Tosi, L., Teatini, P., Carbognin, L., and Frankenfield, J.: A new project to monitor land subsidence in the northern Venice coastland (Italy), Environ. Geol., 52, 889-898, doi:10.1007/s00254006-0530-8, 2006.
Tsai, R. Y.: A versatile camera calibration technique for high accuracy $3 \mathrm{D}$ machine vision metrology using off-the-shelf TV cameras and lenses, IEEE Journal on Robotics and Automation, 3, 323-344, 1987.

Turner, I. L. and Anderson, D. J.: Web-based and 'real-time' beach management system, Coast. Eng., 54, 555-565, 2007.

Uunk, L., Wijnberg, K. M., and Morelissen R.: Automated mapping for the intertidal beach bathymetry from video images, Coast. Eng., 57, 461-469, 2010.

Viet, N. T., Duc, N. V., Binh, L. T., Thuan, D. H., Tung, T. T., Van Uu, D., Lefebvre, J. P., Almar, R., and Tanaka H.: Seasonal evolution of shoreline changes in Nha Trang Bay, Vietnam, Proceedings of the 19th IAHR-APD Congress 2014, Hanoi, Vietnam, 2014.

van Maanen, B., Nicholls, R. J., French, J. R., Barkwith, A., Bonaldo, D., Burningham, H., Murray, A. B., Payo, A., Sutherland, J., Thornhill, G., Townend, I. H., van der Wegen, M., and Walkden, M. J. A.: Simulating mesoscale coastal evolution for decadal coastal management: A new framework integrating multiple, complementary modelling approaches, Geomorphology, 256, 68-80, doi:10.1016/j.geomorph.2015.10.026, 2015.

Vousdoukas, M. I., Ferreira, P. M., Almeida, L. P., Dodet, G., Psaros, F., Andriolo, U., Taborda, R., Silva, A. N., Ruano, A., and Ferreira, O. M.: Performance of intertidal topography video monitoring of a meso-tidal reflective beach in South Portugal, Ocean Dynam., 61, 1521-1540, 2011.

Warner, J. C., Armstrong, B., He, R., and Zambon, J. B.: Development of a Coupled Ocean-Atmosphere-Wave-Sediment Transport (COAWST) Modeling System, Ocean Model., 35, 230-244, doi:10.1016/j.ocemod.2010.07.010, 2010.

Weng, J., Cohen, P., and Herniou, M.: Camera calibration with distortion models and accuracy evaluation, IEEE T. Pattern Anal., 14, 965-980, doi:10.1109/34.159901, 1992.

Wijnberg, K. M., Aarninkhof, S. G. J., Van Koningsveld, M., Ruessink, B. G., and Stive, M. J. F.: Video monitoring in support of coastal management, Proc. Of 29th Int. Conf. on Coastal Engineering, ASCE, Lisbon, Portugal, 3, 3136-3148, 2005.

Zampato, L., Umgiesser, G., and Zecchetto, S.: Storm surge in the Adriatic Sea: observational and numerical diagnosis of an extreme event, Adv. Geosci., 7, 371-378, doi:10.5194/adgeo-7371-2006, 2006.

Zhang, Z.: Flexible Camera Calibration by Viewing a Plane from Unknown Orientations, Microsoft Research, Redmond, USA, 1999.

Zavatarelli, M. and Pinardi, N.: The Adriatic Sea modelling system: a nested approach, Ann. Geophys., 21, 345-364, doi:10.5194/angeo-21-345-2003, 2003.

Zunica, M.: Beach Behavior and Defences along the Lido Di Jesolo, Gulf of Venice, Italy, J. Coastal Res., 6, 709-719, 1990. 